\title{
A vueltas con la Torre Pelli: la polémica creada con la pretensión de exclusión de Patrimonio de la Humanidad de monumentos en Sevilla
}

\author{
Ángel Cabral González-Sicilia \\ Abogado (Socio de Bufete Génova).Vicepresidente de la Asociación Española de Técnicos Urba- \\ nistas (AETU) y Presidente de la Agrupación de Técnicos Urbanistas de Andalucía (ATUA) \\ angel.cabral@bufetegenova.com \\ Recibido: 22 de mayo de 2012 \\ Aceptado: 18 de julio de 2012
}

Resumen

España debe estar orgullosa de tener uno de los ordenamientos jurídicos con mayor tradición, a nivel internacional, en la defensa y protección de su vastísimo patrimonio cultural y de las expresiones histórico-artísticas en orden a que futuras generaciones puedan admirar y disfrutar de ese legado, Ilegando a acuñar conceptos que contribuyen de forma eficaz y efectiva a conservar y realzar los bienes auspiciados tales como el entorno, la armonía del paisaje, la perspectiva o el propio campo visual o perceptivo, al objeto de evitar e impedir la posible contaminación del mismo, y anteponiéndose a conceptos que hoy día aún se discuten en la doctrina. Por otra parte, todos estamos y debemos estar sometidos al imperio del ordenamiento jurídico aplicable y al principio de seguridad jurídica (tanto a nivel internacional como a nivel de unión europea, como a nivel nacional, autonómico y local). Y si ello fuese así, que es como debería de ser, desde la propia comunidad internacional no se podrían admitir y deberían ser repudiados los informes que se han ido sucediendo desde ICOMOS en orden a pretender hacer peligrar la declaración de patrimonio de la Humanidad de que gozan la Catedral de Sevilla, la Lonja o Archivo de Indias y los Reales Alcázares, al estimar, que nunca probar, que la construcción de la denominada Torre Pelli supone una "amenaza" aún cuando ésta no pueda verse, a nivel de viandante, desde los tres monumentos inscritos, siendo sus estados de conservación excepcionalmente buenos.

Dado que los Estados partes han de acatar los postulados de la Convención Internacional sobre la protección del patrimonio mundial, cultural y natural de 1972, del mismo modo y con mayor rigor aún si cabe, deberían acatarlo quienes se erigen como inspectores del estado de conservación de ese patrimonio, cosa que por ICOMOS no se sigue, y desde estas páginas denunciamos a los efectos de que sean corregidos.

Palabras clave

Torre Pelli, principio de seguridad jurídica, normas de aplicación directa, Declaración de Patrimonio de la Humanidad, límites de los informes para la UNESCO, evaluación del Valor Universal Excepcional, paisaje urbano histórico.

\section{About the Pelli Tower: the controversy with the intention to exclude the world heritage the monuments of Seville}

\begin{abstract}
Spain should be proud of having one of the most traditional legal system, internationally, in the defense and protection of its cultural heritage and historical and artistic expressions in order for the future generations to admire and enjoy this legacy, establishing concepts that contribute efficiently and effectively to preserve and enhance sponsored assets such as the enviroment, the harmony of the landscape, perspective or visual or perceptual field itself, in order to avoid and prevent possible contamination of the same, putting before concepts that today are still being discussed in the doctrines. Moreover, we are and we should all be subject to the applicable legal system and the principle of legal certainty (both international and EU level, as national, regional and local). And if that were so, that is as it should be, from the international community itself could not accept and should be repudiates reports that ICOMOS have been doing in order to pretend to put a risk the declaration of World Heritage with the Catedral de Sevilla, la Lonja and Archivo de Indias and the Alcazar, considering, with absolutely no proof, that the construction of the Power Pelli is a threat although this cannot be viewed, at pedestrian area, from three inscribe monuments, their conservation status being exceptionally good. As the Member States must fulfill the principles of the International Convention on the Protection of the World Cultural and Natural Heritage of 1972, in the same way and more rigorously, should be enforced by inspectors of the state of conservation of this heritage, and this is precisely that ICOMOS does not do, so from these pages denounced for this to be corrected.
\end{abstract}

Key words

Pelli Tower, the principle of legal certainty, directly applicable rules, Statement of Heritage, limits to UNESCO reports, assessment of oustanding universal value, historic urban landscape. 


\section{INTRODUCCIÓN}

Desde hace ya casi un siglo que en España se ha venido tomando conciencia y una posición muy activa en orden a conservar, preservar, revalorizar y, en su caso, enriquecer el patrimonio cultural y las expresiones históricoartísticas $^{1}$ en orden a que futuras generaciones puedan admirar y disfrutar de ese legado, concibiéndolos como paradigmas del saber, formativo, educativo, social y económico. Por ello nuestro ordenamiento jurídico, estatal y autonómico, aborda la esencia de la salvaguarda, el amparo, el auxilio proteccionista de dichos valores de forma transversal, desde distintos órdenes, tales como el de Patrimonio, el de la Ordenación del Territorio y el propio Urbanístico, llegando a enunciar, acuñar y desarrollar conceptos que abarcan una zona de influencia que coadyuve a conservar y a realzar los bienes auspiciados tales como el entorno, la armonía del paisaje, la perspectiva o el propio campo visual o perceptivo al objeto de paliar o evitar la posible contaminación del mismo, etc.

Ese rancio y arraigado afán y esmero proteccionista plasmado en nuestro ordenamiento jurídico desde los albores de principios del siglo pasado y fomentado entre la población, hacen que exista una casi unánime conciencia de defensa, custodia y atención de todo aquello que revista una determinada y certera importancia. No digamos ya si se trata de monumentos cuyo valor universal excepcional es del todo punto axiomático, indiscutible e irrefutable.

Por eso no podemos ni aceptar, ni acoger, ni siquiera dar por un actuar válido en cuanto a su fin (que nunca en cuanto a la forma), los informes que se han ido sucediendo desde ICOMOS en orden a pretender hacer peligrar la declaración de patrimonio de la Humanidad de que gozan la Catedral de Sevilla, La Lonja o Archivo de Indias y los Reales Alcázares. Ello es, cuanto menos, desconcertante, pues debemos esa declaración de Patrimonio de la Humanidad a dicha institución, y ahora esa misma organización no gubernamental, es la que lo hace peligrar innoble e ignominiosamente, siendo su principal "amenaza" contra la que debería actuar la propia UNESCO.

Así surge una polémica de presunta "amenaza" de destrucción o deterioro de los bienes de Sevilla inscritos como Patrimonio de la Humanidad, allí donde no tendría que existir, gestada por quien no debiera haberla producido, sin que nadie haya pedido auxilio o ayuda, sin apoyo jurídico certero y serio, violentando y quebrantando, con dicho proceder, el elemental e internacional principio de seguridad jurídica. En palabras de Charles Édouard Jeanneret-Gris ("Le Corbusier") "la arquitectura esta reprimida por la costumbre...".

\section{LA CONVENCIÓN DE PATRIMONIO MUNDIAL}

La idea de crear un movimiento internacional para la protección del patrimonio surgió tras la Primera Guerra Mundial, despertando esta inquietud y la preocupación internacional por la resolución de erigir la presa de Asuán en Egipto, al preverse la inundación del valle que albergaba los templos de Abu Simbel. Así la UNESCO² inició, con la ayuda del Consejo Internacional de Monumentos y Sitios $(\mathrm{ICOMOS})^{3}$, la preparación de un proyecto de convención sobre la protección del patrimonio cultural.

La Convención para la Protección del Patrimonio Mundial, Cultural y Natural fue aprobada por la Conferencia General de la UNESCO el 16 de noviembre de $1972^{4}$, considerando el patrimonio en su doble aspecto cultural y natural, expresando un compromiso compartido en la preservación de nuestro legado para las generaciones futuras. En el texto de dicha Convención se incluye la definición del Patrimonio Cultural y Natural. Centrándonos en el "patrimonio cultural", señalar que éste engloba a "los monumentos", "los conjuntos" y "los lugares", y para nuestro análisis interesa conocer las dos primeras locuciones que tienen la siguiente definición:

“A) los monumentos: obras arquitectónicas, de escultura o de pintura monumentales, elementos o estructuras de carácter arqueológico, inscripciones, cavernas y grupos de elementos, que tengan un valor universal excepcional desde el punto de vista de la historia, del arte o de la ciencia,

B) los conjuntos: grupos de construcciones, aisladas o reunidas, cuya arquitectura, unidad e integración en el paisaje les dé un valor universal excepcional desde el punto de vista de la historia, del arte o de la ciencia"s.

$1 \quad$ V., a mero título de ejemplo, el Real Decreto-Ley de 9 agosto de 1926, relativo al tesoro artístico arqueológico nacional.

2 La Organización de las Naciones Unidas para la Educación, la Ciencia y la Cultura (United Nations Educational, Scientific and Cultural Organization, abreviado internacionalmente como UNESCO) -1946-, pretende crear condiciones propicias para un diálogo entre las civilizaciones, las culturas y los pueblos fundado en el respeto de los valores comunes.

3 Fundado el año 1965 en Varsovia (Polonia). El Consejo Internacional de Monumentos y Sitios Histórico-Artísticos (ICOMOS) es una organización internacional no gubernamental, y en lo que se refiere a la Convención para la Protección del Patrimonio Mundial, Cultural y Natural, la función concreta del ICOMOS consiste en: "evaluar los bienes propuestos para ser incluidos en la Lista del Patrimonio Mundial, supervisar el estado de conservación de los bienes culturales del Patrimonio Mundial, estudiar las solicitudes de asistencia internacional presentadas por los Estados Partes y prestar su contribución y apoyo a las actividades de formación de capacidades" [Punto I.G.35 de las Directrices Prácticas para la aplicación de la Convención del Patrimonio Mundial (denominadas en adelante, las “Directrices Prácticas")].

$4 \quad$ España se adhirió a dicha Convención en el año 1982.

5 Artículo $1^{\circ}$ de la Convención para la Protección del Patrimonio Mundial, Cultural y Natural (en adelante, Convención-1972). 
También se instituye la obligatoriedad primordial de cada Estado Parte de identificar, proteger, conservar, rehabilitar y transmitir a las generaciones futuras el patrimonio cultural y natural situado en su territorio ${ }^{6}$, fundándose un Patrimonio Universal 7 y comprometiéndose la comunidad internacional a cooperar en su protección, e imponiéndose a que dichos Estados no causen daño a dicho patrimonio, ya sea por medidas directas o indirectas ${ }^{8}$. Para ello, se entiende por "protección internacional del patrimonio mundial cultural", "el establecimiento de un sistema de cooperación y asistencia internacional destinado a secundar a los Estados Partes en la Convención en los esfuerzos que desplieguen para conservar e identificar ese patrimonio".

Asimismo, se crea el "Comité de Patrimonio Mundial"”, teniendo voz consultiva en el mismo, entre otros, un representante del ICOMOS" (organismo consultivo). $Y$ a dicho Comité los Estados firmantes han de remitir un inventario de bienes susceptibles de ser integrados en la "Lista de patrimonio mundial" ${ }^{12}$, por ostentar un valor universal excepcional.

El Comité establece, igualmente, una "Lista del Patrimonio Mundial en Peligro"'13, que incluirá aquellos bienes de la Lista de patrimonio mundial, cuya protección exija grandes trabajos de conservación para los que se haya solicitado ayuda ${ }^{14}$ ("peticiones de ayuda internacional"15 o "asistencia internacional"16), sobre aquellos bienes amenazados por "peligros graves y precisos", y para ello se crea el "Fondo del Patrimonio Mundial" principio, la inscripción de un bien en esta lista permitiría obtener financiación para su restauración.

No obstante, se aclara que la no inscripción en alguna de estas listas no significa que no tenga un determinado bien un valor universal excepcional, y parece que dicha inclusión en la Lista ha de atenerse a los específicos fines, Categorías ${ }^{18}$ y Criterios por los que se inscribió ${ }^{19}$.

El término "valor universal excepcional" ${ }^{20}$ (OUV), consecuentemente, debemos concebirlo como de significado cultural y/o natural tan particular, único y exclusivo que trasciende de los confines y territorios nacionales para ser de trascendencia, significación, magnitud y excelencia para toda la humanidad, que debe preservarse de forma permanente, sobre todo, como esencial, básico, primario e importantísimo legado para las futuras generaciones. Y si se destruye dicho Valor Universal Excepcional del bien que justificó la inscripción en la Lista del Patrimonio Mundial, el Comité considerará la posibilidad de excluir el bien de la Lista ${ }^{21}$.

\section{A) La inscripción en la Lista del Patrimonio Mundial y los límites de la misma}

De forma taxativa se impone que "en el momento de inscribir un bien en la Lista del Patrimonio Mundial, el Comité adopta una Declaración de Valor Universal Excepcional que servirá de referencia clave para la protección y la gestión eficaz del bien en el futuro"22.

Esa Declaración de Valor Universal Excepcional incluirá un resumen de la decisión del Comité que acredite el Valor Universal Excepcional del bien, en cuya virtud se exponen los criterios que justifican su inscripción en la Lista, incluidas las valoraciones de las condiciones de integridad y/o autenticidad y las medidas de protección y gestión vigentes. De esta forma, la Declaración de Valor Universal Excepcional (OUV) ${ }^{23}$ servirá de base para la protección y gestión del bien en el futuro ${ }^{24}$.

Del mismo modo, se aclara que en el momento de la inscripción, el Comité podrá formular otras recomendaciones relativas a la protección y la gestión del bien del Patrimonio Mundial.

\footnotetext{
6 Vid arts. 4 y 5 de la Convención-1972.

7 Ex art. 6.1 de la Convención-1972.

8 Ex art. 6.3 de la Convención-1972.

9 Ex art. 7 de la Convención-1972.

10 Comité intergubernamental de protección del patrimonio cultural y natural de valor universal excepcional (art. 8.1 de la Convención-1972).

Ex art. 8.3 de la Convención-1972.

Ex art. 11.1 de la Convención-1972.

El artículo 11.4 de la Convención-1972.

Vid asimismo art. 13 de la Convención-1972.

Art. 13.2 de la Convención-1972.

Ex art. 19 de la Convención-1972.

Vid arts. 15 y ss. de la Convención-1972.

18 Recuérdese que el Patrimonio Cultural prevé 3 Categorías o clases, según dijimos (Los monumentos, los conjuntos y los lugares)

-ex art. 1 de la Convención-1972-.

Lo que se deduce del propio art. 12 de la Convención-1972.

20 Punto 49 (dentro del apartado II.A) de las Directrices Prácticas para la aplicación de la Convención del Patrimonio Mundial.

Vid punto I.B.9 de las Directrices Prácticas.

2 Punto (o párrafo) 51 (dentro del apartado II.A) de las Directrices Prácticas para la aplicación de la Convención del Patrimonio Mundial.

Punto (o párrafo) 154 (dentro del apartado III.G) de las Directrices Prácticas para la aplicación de la Convención del Patrimonio Mundial.

4 Punto (o párrafo) 155 (dentro del apartado III.G) de las Directrices Prácticas para la aplicación de la Convención del Patrimonio Mundial.
} 
Todos los bienes incluidos en la Lista del Patrimonio Mundial deben contar con mecanismos de protección y gestión legislativos, reglamentarios, institucionales y/o tradicionales adecuados que garanticen su salvaguarda a largo plazo. Esta protección ha de abarcar unos límites claramente definidos, de ahí que se exija que "en la propuesta de inscripción tendrán que adjuntar textos que contengan una clara explicación sobre cómo se implementa la protección jurídica del bien en cuestión”25.

Interesa resaltar también que el "monitoreo reactivo"26 (misión o procedimiento específico) consiste en la presentación al Comité, por la Secretaría, otros sectores de la UNESCO y los organismos consultivos, de informes sobre el estado de conservación de determinados bienes del Patrimonio Mundial amenazados, cuyo principal objeto es "velar por que se adopten todas las medidas posibles para impedir la exclusión de cualquier bien de la Lista"27.

\section{B) Criterios para la inclusión de un bien en la Lista del Patrimonio Mundial.}

El Comité define los criterios de evaluación del Valor Universal Excepcional que han de servir de base para la inscripción de un bien del patrimonio cultural y natural la Lista de Patrimonio Mundial²8.

Las “Directrices Prácticas" tienen por objeto facilitar la aplicación de la Convención para la Protección del Patrimonio Mundial Cultural y Natural y se revisan periódicamente para reflejar las decisiones del Comité del Patrimonio Mundial. En dichas Directrices Prácticas se manifiesta que las Partes de la Convención del Patrimonio Mundial, se comprometen, entre otras cosas, a "no adoptar deliberadamente medidas que puedan causar daño, directa o indirectamente, a su patrimonio o al de otro Estado Parte de la Convención"29.

El Comité considera que un bien posee Valor Universal Excepcional si cumple uno o más de los siguientes criterios. Por lo tanto, los bienes propuestos tendrán (en lo que ahora interesa) que:

“(i) representar una obra maestra del genio creador humano;

(ii) atestiguar un intercambio de valores humanos considerable, durante un periodo concreto o en un área cultural del mundo determinada, en los ámbitos de la arquitectura o la tecnología, las artes monumentales, la planificación urbana o la creación de paisajes;

(iii) aportar un testimonio único, o al menos excepcional, sobre una tradición cultural o una civilización viva o desaparecida;[...]

(vi) estar directa o materialmente asociado con acontecimientos o tradiciones vivas, ideas, creencias $u$ obras artísticas y literarias que tengan una importancia universal excepcional. (El Comité considera que este criterio debería utilizarse preferentemente de modo conjunto con los otros criterios) [...]"30.

Para ser considerado de Valor Universal Excepcional, el bien además debe reunir las condiciones de integridad y/o autenticidad y debe contar con un sistema de protección y gestión adecuado que garantice su salvaguardia. $Y$ así se precisa lo que se estima por integridad y/o autenticidad. La declaración de autenticidad evaluará el grado de veracidad presente o expresado en cada uno de los atributos importantes. La integridad mide el carácter unitario e intacto del patrimonio natural y/o cultural y de sus atributos.

La protección y la gestión de los bienes declarados Patrimonio Mundial deben garantizar que el Valor universal Excepcional y las condiciones de integridad y/o autenticidad en el momento de la inscripción en la lista se mantengan o mejoren en el futuro ${ }^{31}$.

Interesa señalar que "Los juicios sobre el valor atribuido al patrimonio cultural y la credibilidad de las fuentes de información pueden diferir de una cultura a otra, e incluso dentro de la misma cultura. El respeto debido a todas las culturas exige que el patrimonio cultural sea estudiado y juzgado fundamentalmente dentro de los contextos culturales a los que pertenece"32.

Precisar, igualmente, que la evaluación de las propuestas de inscripción de bienes culturales será realizada por el ICOMOS 33 .

25 Punto (o párrafo) 97 (dentro del apartado II.F) de las Directrices Prácticas para la aplicación de la Convención del Patrimonio Mundial.

26 Vid Punto (o párrafo) 169 y ss. (dentro del apartado IV.A) de las Directrices Prácticas para la aplicación de la Convención del Patrimonio Mundial ("Reactive Monitoring”).

27 Punto (o párrafo) 170 (dentro del apartado IV.A) de las Directrices Prácticas para la aplicación de la Convención del Patrimonio Mundial.

28 Ex art. art. 11.5 de la Convención-1972.

29 Punto I.C.15.h) de las Directrices Prácticas, en relación con el art. 6.3 de la Convención-1972.

30 Punto (o párrafo) 77 (dentro del apartado II.D) de las Directrices Prácticas para la aplicación de la Convención del Patrimonio Mundial.

31 Punto (o párrafo) 96 (dentro del apartado II.F) de las Directrices Prácticas para la aplicación de la Convención del Patrimonio Mundial.

32 Punto (o párrafo) 81 (dentro del apartado II.E) de las Directrices Prácticas para la aplicación de la Convención del Patrimonio Mundial.

33 Punto (o párrafo) 144 (dentro del apartado III.E) de las Directrices Prácticas para la aplicación de 


\section{C) Los límites para una protección eficaz}

La definición de límites constituye un requisito indispensable para la protección eficaz de los bienes que se proponen inscribir, dado que una vez inscritos a ellos habrá que estar, en base a un evidente y notorio principio de seguridad jurídica. Esos contornos se establecen con el fin de asegurar la plena expresión del Valor Universal Excepcional y la integridad y/o autenticidad del bien, aparte de dotar al sistema de cierto grado de seguridad jurídica, debiendo desterrarse cualquier atisbo o conato de "arbitrariedad". Y en el caso de los bienes propuestos según los criterios (i) (vi), "los límites se establecerán de manera que incluyan todas las áreas y los atributos que sean expresión tangible directa del Valor Universal Excepcional del bien, además de las áreas que, considerando posibilidades futuras de investigación, podrían contribuir a su comprensión y a mejorar ésta" ${ }^{34}$.

Los límites del bien propuesto podrán coincidir con una o varias zonas protegidas existentes o propuestas, como por ejemplo "un barrio histórico protegido"35. Por esta razón el que se instaure la denominada "Zona de amortiguamiento", entendida ésta como "área alrededor del bien cuyo uso y desarrollo están restringidos jurídica y/o consuetudinariamente a fin de reforzar su protección" ${ }^{36}$ (entorno inmediato). Así se enuncia que "cuando la conservación adecuada del bien lo requiera, deberá establecerse alrededor del bien una zona amortiguamiento" ${ }^{37}$.

Dicha "Zona de amortiguamiento" (o "zona tampón de amortiguamiento") deberá estar incluida en la propia Propuesta de inscripción, detallando "la extensión, las características y usos autorizados [...] ], así como un mapa donde que se indiquen los límites exactos tanto del bien" ${ }^{8}$. Y en los supuestos en que no se proponga una zona de amortiguamiento, la solicitud de inscripción debe incluir una declaración en la que se explique por qué no es necesaria una zona de amortiguamiento. A mayor abundamiento "cualquier modificación de la zona tampón de amortiguamiento realizada con posterioridad a la inscripción del bien en la Lista del Patrimonio Mundial tendrá que obtener la aprobación del Comité del Patrimonio Mundial"39.

\section{D) Criterios para la inscripción de un bien en la Lista del Patrimonio Mundial en Peligro}

El Comité podrá incluir en la Lista del Patrimonio Mundial en Peligro un bien del Patrimonio si estima que la situación del mismo corresponde al menos a uno de los dos peligros que se reconocen como tales: el comprobado o el potencial. Si bien estos supuestos están expresa y puntualmente tasados. Así, se entiende peligro comprobado (en el supuesto de bienes culturales) cuando, por ejemplo, existe grave alteración de los materiales, de las estructuras y/o la ornamentación, de la coherencia arquitectónica o urbanística, del espacio urbano, del significado cultural o por la pérdida significativa de la autenticidad histórica ${ }^{40}$.

Se estima que existe peligro potencial (en el supuesto de bienes culturales) cuando, entre otras causas, puedan existir repercusiones perjudiciales en sus características esenciales ${ }^{41}$, como podría ser, por ejemplo, por el peligro originado por un plan urbanístico.

\section{PROPUESTA, CRITERIOS E INSCRIPCIÓN EN LA LISTA DE PATRIMONIO MUNDIAL DE LOS TRES MONUMENTOS DE SEVILLA}

En 1986, a petición de ICOMOS, el Gobierno de España, incluye tres monumentos principales en una única nominación en Sevilla: la Catedral, el Alcázar y la Lonja (convertido en 1784 el Archivo General de Indias), que originalmente fueron nominados por separado.

La contigüidad, inmediación y colindancia de estos tres monumentos en el corazón de la ciudad de Sevilla, su notoria, evidente y axiomática sinergia, simbiosis y complementariedad y el hecho de que estén representados en ellos todos los puntos relevantes de la historia de Sevilla y de su reflejo en el resto del mundo, aportaba gran coherencia, congruencia y lógica en dicha propuesta, en vez de realizar unas propuestas individualizadas, de ahí que en vez de ser considerados de forma independiente como monumentos, se haga una inscripción algo "sui generis" por cuanto serán "conjunto" (monumental)42, aunque luego en la declaración se aluda a "Complejo monumental”.

34 Punto (o párrafo) 99 (dentro del apartado II.F) de las Directrices Prácticas para la aplicación de la Convención del Patrimonio Mundial.

35 Punto (o párrafo) 102 (dentro del apartado II.F) de las Directrices Prácticas para la aplicación de la Convención del Patrimonio Mundial.

36 Punto (o párrafo) 104 (dentro del apartado II.F) de las Directrices Prácticas para la aplicación de la Convención del Patrimonio Mundial.

37 Punto (o párrafo) 103 (dentro del apartado II.F) de las Directrices Prácticas para la aplicación de la Convención del Patrimonio Mundial.

38 Punto (o párrafo) 104 (dentro del apartado II.F) de las Directrices Prácticas para la aplicación de la Convención del Patrimonio Mundial. Vid también punto 132 .

39 Punto (o párrafo) 107 (dentro del apartado II.F) de las Directrices Prácticas para la aplicación de la Convención del Patrimonio Mundial. Asimismo vid punto 163 (Modificaciones de los límites de un bien del Patrimonio Mundial) y ss.

40 Vid Punto (o párrafo) 179 (dentro del apartado IV.B) de las Directrices Prácticas para la aplicación de la Convención del Patrimonio Mundial.

41 Por ejemplo, con la modificación de la condición jurídica del bien, que pueda disminuir el grado de protección; o la carencia de una política de conservación; o por peligros derivados de proyectos de ordenación territorial; o por peligros causados por planes urbanísticos; o por estallido o amenaza de conflicto armado; o por cambios paulatinos debidos a factores geológicos o climáticos, o a otros factores ambientales.

42 Pero considerados como "conjunto" en la definición del artículo $1^{\circ}$ visto de la Convención. 
En 1987 fue aceptada la propuesta y estas propiedades culturales fueron incluidas en la lista del patrimonio mundial, si bien dejar claro que no se definió ninguna zona de amortiguación. Así se determinó que el estado de las fronteras del sitio se consideraba adecuada y que no se definía “zona de amortiguamiento" por resultar innecesaria puesto que El Alcázar resulta ser un recinto amurallado y protegido43. Y el Bien denominado como "Catedral, Alcázar y Archivo de Indias de Sevilla”, fue inscrito el 11 de diciembre de 1987 en el Registro de Bienes pertenecientes al Patrimonio Mundial de la UNESCO.

Tras ese preceptivo resumen de la declaración se manifiestan los expresos Criterios por los que han sido inscritos (como Conjunto) ${ }^{44}$.

El número de bienes inscritos en la lista de Patrimonio Mundial va aumentando sobremanera con el decurso de los años, coincidiendo con los flujos turísticos, y al mismo tiempo de la aplicación de la Convención y al objeto de aminorar los riesgos que pudieran existir sobre numerosos bienes inscritos en la Lista de Patrimonio Mundial, el Comité va aumentando la complejidad y el número de medidas de protección y de gestión requeridas antes de aceptar la inscripción de un bien en Patrimonio Mundial. Es por ello que últimamente ha venido solicitando documentos cada vez más precisos y amplios en sus enunciados, pretensiones y justificaciones de los valores universales excepcionales, así como de análisis comparativos con otras zonas similares, incorporando finalmente los planes de protección y sobretodo de gestión. Así, en los primeros años de funcionamiento de la Convención, se entendía que las propias las leyes nacionales eran suficientes para tutelar y proteger un bien inscrito en la Lista ${ }^{45}$.

En el supuesto fáctico del "Conjunto monumental" de Sevilla debemos recordar que fue inscrito en la Lista de Patrimonio Mundial antes de que existiese la necesidad de presentar un plan de gestión. Ahora bien, el informe periódico de 2006 sobre el estado de conservación del "conjunto monumental" de Sevilla, estima que toda la situación de Patrimonio Mundial de Sevilla responde a la Convención y a las Directrices y no necesita de dicho plan de gestión. Del mismo modo, apuntar que desde que se inscribió el "conjunto monumental" de Sevilla no se vio ninguna necesidad de instaurar ninguna zona de amortiguamiento ("Buffer zone"), y en el indicado informe periódico de 2006 se razonó que no necesitaba de esa zona de amortiguamiento dado que: "el patrimonio mundial de Sevilla, especialmente El Alcázar, es un sitio rodeado de muros, protegido". Y aun existiendo esas mismas circunstancias, ahora se cambia de justificaciones y razonamientos. Y según el propio Informe de ICOMOS de Noviembre de 2011 podemos aclarar los aspectos de Integridad ${ }^{46}$, autenticidad ${ }^{47}$, protección y gerencia ${ }^{48}$.

43 Boundaries and Buffer Zone. • Status of boundaries of the site: adequate. • Buffer zone: no buffer zone has been defined; buffer zone not needed because The Alcazar is a walled, protected site. Need for measures to protect against environmental factors.

44 Criterio (i): la Giralda constituye un logro artístico único, una obra maestra de la arquitectura almohade. La inmensa Catedral con cinco naves, que sustituyó a la mezquita es el edificio gótico más grande de Europa. El espacio elíptico del Cabildo, creado por Hernán Ruiz, es una de las más bellas obras arquitectónicas del Renacimiento. Criterio (ii): la Giralda, influencia la construcción de numerosas torres de España y después de la conquista, en las Américas. Criterio (iii): el templo gótico más grande en Europa: de la Catedral y los Reales Alcázares de Sevilla son testimonio excepcional de la civilización Almohade y de la Andalucía cristiana que datan de la reconquista de 1248 del siglo XVI, que fue minuciosamente imbuido con influencia morisca. (...) Criterio (vi): la Catedral, el Alcázar y la Lonja están directa y tangiblemente asociadas a un evento universalmente importante: el descubrimiento del nuevo mundo por Cristóbal Colón en 1492 y 1493 y la colonización de América Latina. Se conserva la tumba de Cristóbal Colón en la Catedral. En la Sala de los Almirantes hicieron planes para una serie de exploraciones más grandes de la historia, en particular la circunnavegación del globo por Magallanes y Sebastián El Cano (1519-1522). En la Lonja se conservan más preciosos documentos de los archivos de las colonias en América.

45 Con posterioridad se erige el plan de gestión del bien en una obligación para todos los bienes inscritos.

46 Integridad (2010) "El Conjunto Monumental conserva en su configuración la integridad física de los edificios originales y la yuxtaposición de las diversas etapas históricas más importantes. La Catedral constituye un monumento completo y plenamente utilizado. Un templo gótico cuya construcción se inició a comienzos del siglo XV por encima de la Mezquita mayor de Sevilla, un edificio almohade cuyo Patio de los Naranjos se ha preservado y convertido en el patio de acceso a la Catedral y de la Giralda el minarete que ha sido reutilizado como un campanario. Muestra claramente la construcción de mampostería gótico original. Asimismo, los edificios posteriores del Renacimiento, como la Sala Capitular (sala capitular) conservan a su estructura original. El Alcázar es otro monumento que conserva la integridad de las fases de los distintos periodos en que fue construido. Las habitaciones, patios y jardines del palacio almohade original se conservan en su estado original, como son las construcciones mudéjares que componen el Palacio de Pedro I y los restantes posteriores construcciones y jardines que conforman el actual Conjunto Monumental. La construcción del Archivo de Indias se conserva en su totalidad, junto con los documentos valiosos que contiene".

47 Autenticidad(2010) "Cada uno de los tres edificios refleja claramente sus historias arquitectónicas y transmite sus funciones en la "Edad de oro" española en términos de soberanía real poder eclesiástico y el poder comercial que España adquirió a través de sus colonias en el nuevo mundo. En el perímetro restringido cubierto por la propiedad, los tres edificios son las manifestaciones más importantes del poder y la influencia del comercio español en las Américas. Que sin embargo no son las únicas manifestaciones en la ciudad y a reforzar su capacidad de transmitir el valor universal excepcional de la propiedad, es necesario que puedan asociarse con otros edificios restantes. La autenticidad de la serie de estos tres edificios es hasta cierto punto vulnerable a cambios en su configuración que podría dejarlos aislados de otros edificios asociados".

48 Protección y Gerencia requerida (2010). "Mantener el sobresaliente valor Universal sigue siendo garantizado gracias a los mecanismos de protección individuales para cada una de las propiedades inscritas. Los tres edificios disfrutan del más alto grado de protección que existe en la legislación de patrimonio, en los niveles regionales y nacionales, ya que han sido declarados para ser propiedades de interés Cultural en la categoría de monumentos. Asimismo se garantiza la conservación de edificios individuales también asociados con el comercio español en las Américas en el corazón histórico de la ciudad que sirve como escenario urbano de los tres monumentos y las características generales de ese entorno urbano. Cumpliendo con el requisito legal de la existencia de planes urbanos específicos y catálogos para su protección, esta área, como un todo ha sido declarada bien de interés Cultural. Dada la enorme extensión de este Conjunto Histórico, los Planes de Protección se han elaborado de acuerdo a sectores homogéneos. Estos planes especiales y catálogos, junto con el Plan General que entró en vigor en 2006 (para aquellos sectores cuyo catálogo todavía tiene que ser completado), establecen medidas adecuadas para la protección del entorno inmediato de la propiedad. No hay actualmente 
A ello se debe unir lo que por la Gerencia de Urbanismo del Excmo. Ayuntamiento de Sevilla se ha ido informando sobre el estado de conservación como para poder sostener que el estado de conservación de la Catedral, Alcázar y Archivo de Indias de Sevilla ${ }^{49}$ es MUY BUENO, y que trasciende incluso de lo meramente técnico respecto al completo y complejo programa de intervenciones de mantenimiento y conservación, puesta en valor y recuperación de ámbitos o sectores de edificio que aún no son visitables o reconocibles, con el que cuentan cada uno de ellos bajo sus respectivos órganos gestores, que en algún caso cuentan incluso con cuadrillas de operarios especializados y con equipos profesionales liderados por Arquitectos de reconocido prestigio ${ }^{50}$.

Otros indicativos, como por ejemplo el número de visitantes, fundamentalmente al Alcázar y la Catedral, por la lógica especificidad del Archivo (pese a lo señalado en el párrafo anterior), no harían más que profundizar y reafirmar en lo manifestado, pues basta con observar el listado numérico que se acompaña, para concluir en que los datos de 2011, ratifican que el turismo vuelve a repuntar con fuerza en estos dos "buques insignias" de la oferta patrimonial sevillana:

\begin{tabular}{|l|l|l|l|}
\hline Visitantes & 2007 & 2008 & 2009 \\
\hline Catedral & 1.381 .980 & 1.323 .479 & 1.212 .380 \\
\hline Alcázar & 1.139 .293 & 1.085 .647 & 1.080 .302 \\
\hline
\end{tabular}

\begin{tabular}{|l|l|l|}
\hline Visitantes & 2010 & 2011 \\
\hline Catedral & 1.305 .000 & 1.350 .000 \\
\hline Alcázar & 1.176 .792 & 1.272 .667 \\
\hline
\end{tabular}

En lo que respecta a la conservación del "vacío público", del marco de relación y puesta en valor "ciudadano" de estos monumentos, y cuya gestión y control es en gran medida del Ayuntamiento de Sevilla bajo la tutela de la Consejería de Cultura de la Junta de Andalucía, podríamos de nuevo afirmar, sin pudor ni falsa modestia, que su estado es Muy Bueno, pues todas las intervenciones de reurbanización que se han venido abordando en años siguientes a la declaración por parte de la UNESCO y especialmente en los últimos años lo han sido en el sentido de afianzar los valores: público, medioambiental, cultural patrimonial y sostenible. Así, se ha mejorado e incrementado el espacio peatonal frente al destinado al tráfico rodado; intervención de mejora en la calidad de las infraestructuras y equipamientos urbanos: redes de saneamiento, alumbrado, comunicaciones, pavimentos, ajardinamiento y mobiliario ${ }^{51}$.

Que junto con otras actuaciones más específicas y de alcance menor han contribuido a consolidar el entorno monumental de Alcázar, Catedral y Archivo de Indias, como corazón patrimonial de Sevilla, "salón principal" del Conjunto Histórico de Sevilla que abarca no sólo el antiguo recinto amurallado de la ciudad, sino arrabales históricos como el de Macarena, San Bernardo, Calzada o Triana, además de la herencia patrimonial de la Exposición Iberoamericana de 1929 y el Conjunto de la Cartuja; ámbito que en total abarca una superficie de 783,5 hectáreas.

\section{PROTECCIÓN LEGISLATIVA Y DECLARACIONES BIC}

Evoquemos, ante todo, que son deberes y atribuciones esenciales de la Administración del Estado, de conformidad con lo establecido en los artículos $46^{52}$ y $44^{53}$, 149.1.1, y 149.2 de la Constitución, garantizar, por los poderes

planes de acción para los tres edificios. Sin embargo, existen disposiciones para mejorar el área comprendida dentro de una zona de amortiguación, cuya frontera está bajo consideración. En el mediano plazo, las disposiciones introducidas por el Consejo de la ciudad incluyen la realización de los catálogos de edificios para protegerse tanto de los sectores de Conjunto Histórico que no aún no elaborados (sector 7, "Catedral” y sector 8, "Sector de Magdalena de la Encarnación") para reemplazar las actuales precatalogadas. En el mediano plazo, hay planes para restaurar dos edificios en la zona de amortiguación de propuestas que se refieren a la colonización de América Latina, las Atarazanas (astillero) y el Palacio de San Telmo".

49 Alcázar, Catedral y Archivo de Indias, corresponde propiedad y gestión respectivamente a tres instituciones distintas. El $1^{\circ}$ es titularidad del Ayuntamiento de Sevilla. El $2^{\circ}$ de la Iglesia Católica a través de la Archidiócesis de Sevilla. El $3^{\circ}$ al Ministerio de Educación, Cultura y Deporte. Además cuentan con organismos de gestión y control particulares especializados, no sólo en la Administración del Patrimonio, sino en su puesta en valor, su control, mantenimiento y rehabilitación, programación de visitas, intervenciones, difusión y divulgación de sus valores, investigación, etc., plenamente consolidados y muy profesionalizados.

50 Como en el caso del Maestro Mayor de la Catedral, el Doctor Arquitecto D. Alfonso Jiménez Martín y el Conservador del Alcázar D. Jacinto Pérez Eliot. En el caso del Archivo de Indias se ha realizado en los últimos años y por parte del propio Ministerio de Cultura una completísima intervención de rehabilitación integral dirigida por el Arquitecto D. Antonio Campos Alcaide (con programa liderado por su Directora de apertura social y divulgación del edificio y sus contenidos).

51 Destacando en este sentido, los proyectos de: Reurbanización y Peatonalización de la Plaza Virgen de los Reyes y Plaza del Triunfo durante el periodo 1999-2000. Reurbanización de la Plaza de la Contratación y calles San Gregorio, Miguel de Mañara, Deán Miranda, La Roldana y Mariana de Pineda, que comenzaron en 16 de julio de 2007 y finalizaron el 19 de septiembre de 2008 . Actualización de peatonalización de la Avenida y trazado de instalación del Tranvía Metro-Centro, que finalizó el 1 de octubre de 2007.

52 "Los poderes públicos garantizarán la conservación y promoverán el enriquecimiento del patrimonio histórico, cultural y artístico de los pueblos de España y de los bienes que lo integran, cualquiera que sea su régimen jurídico y su titularidad. La ley penal sancionará los atentados contra este patrimonio".

53 "Los poderes públicos promoverán y tutelarán el acceso a la cultura, a la que todos tienen derecho". 
públicos, la conservación del Patrimonio Histórico Español, así como promover el enriquecimiento del mismo y fomentar y tutelar el acceso de todos los ciudadanos a los bienes comprendidos en él.

Según la Ley 16/1985 del 25 de junio de 1985, del Patrimonio Histórico Español54, "son Monumentos aquellos bienes inmuebles que constituyen realizaciones arquitectónicas o de ingeniería, u obras de escultura colosal siempre que tengan interés histórico, artístico, científico o social" ${ }^{55}$, y un "Conjunto Histórico es la agrupación de bienes inmuebles que forman una unidad de asentamiento, continua o dispersa, condicionada por una estructura física representativa de la evolución de una comunidad humana por ser testimonio de su cultura o constituir un valor de uso y disfrute para la colectividad. Asimismo es Conjunto Histórico cualquier núcleo individualizado de inmuebles comprendidos en una unidad superior de población que reúna esas mismas características y pueda ser claramente delimitado"56.

Los tres están inscritos como Bienes de Interés Cultural, con la categoría de Monumento. A saber:

A) La Catedral de Sevilla está inscrito ${ }^{57}$ como Bien de Interés Cultural, en la Tipología Jurídica de Monumento, lo que fue publicado en Gaceta 08/01/192958.

B) La Lonja está catalogada como Bien de Interés Cultural con categoría de Monumento, según publicación oficial del BOE del 03/06/1983

C) El conjunto de los Reales Alcázares está catalogado como Bien de Interés Cultural con categoría de Monumento, según publicación en La Gaceta de Madrid del 04/06/193160.

Por su parte están dentro del Conjunto Histórico (a su vez Bien de Interés Cultural) de Sevilla declarado por Decreto $2.803 / 1964$, de 27 de Agosto ${ }^{61}$ y posteriormente ampliado el ámbito de la delimitación del mismo por el Real Decreto 1.339/1990, de 2 de Noviembre. Se trata de un vasto e inmenso Conjunto Histórico de 7.835.000 m2 con un total de 6.875 fincas catalogadas.

Hemos de precisar, además, que la Comunidad Autónoma de Andalucía cuenta con un ordenamiento jurídico propio para la protección del Patrimonio Histórico ${ }^{62}$, en cuyo núcleo se encontraba la Ley 1/1991, de 3 de julio, de Patrimonio Histórico de Andalucía derogada por la actual Ley 14/2007, de 26 de noviembre. Con esa última norma se afronta la protección del Patrimonio Histórico desde un enfoque territorial, acentuando la coordinación con la legislación urbanística, tras la aprobación de la Ley 7/2002, de 17 de diciembre, de Ordenación Urbanística de Andalucía.

La legislación del Patrimonio, tanto la Ley nacional como la andaluza, así como todas las autonómicas, han otorgado al planeamiento urbanístico una función esencial en la tarea de protección integral de los bienes que lo conforman, con particular incidencia en la tutela de los Conjuntos Históricos, Sitios Históricos y Zonas Arqueológicas, así como en los entornos de Monumentos, a los que la nueva Ley andaluza añade los Lugares de Interés Etnológico, Lugares de Interés Industrial y las Zonas Patrimoniales.

54 Tal y como se reconoce en la Exposición de Motivos del Real Decreto núm. 111/1986, de 10 de enero, de desarrollo parcial de la Ley 16/1985, de 25 de junio, del Patrimonio Histórico Español, esta Ley “establece el nuevo marco jurídico para la protección, acrecentamiento y transmisión a las generaciones futuras del Patrimonio Histórico Español”. Y según se predica del propio Preámbulo de la Ley el “Patrimonio Histórico Español es el principal testigo de la contribución histórica de los españoles a la civilización universal y de su capacidad creativa contemporánea. La protección y el enriquecimiento de los bienes que lo integran constituyen obligaciones fundamentales que vinculan a todos los poderes públicos, según el mandato que a los mismos dirige el artículo 46 de la norma constitucional".

55 Art. 15.1 de la Ley $16 / 1985$ del 25 de junio de 1985 .

56 Art. 15.3 de la Ley $16 / 1985$ del 25 de junio de 1985.

57 En el Registro General de Bienes de Interés Cultural.

58 Denominación: Iglesia Catedral de Santa María. Otras denominaciones: Iglesia Catedral de Santa María; Antigua Mezquita-lglesia Catedral de Santa María. Código (Instituto Andaluz del Patrimonio Histórico, Consejería de Cultura, Junta de Andalucía): 01410910111 (Caracterización: Arqueológica, Arquitectónica).

59 Denominación: Antigua Casa Lonja. Otras denominaciones: Archivo General de Indias; Lonja de Mercaderes. Código (Instituto Andaluz del Patrimonio Histórico, Consejería de Cultura, Junta de Andalucía): 01410910089 (Caracterización: Arqueológica, Arquitectónica).

60 Denominación: Reales Alcázares. Otras denominaciones: Patio de Banderas. Código (Instituto Andaluz del Patrimonio Histórico, Consejería de Cultura, Junta de Andalucía): 01410910109 (Caracterización: Arqueológica, Arquitectónica).

61 Por el entonces Ministerio de Educación Nacional, formulado de conformidad con lo dispuesto en la Ley de Patrimonio Artístico Nacional de 13 de mayo de 1933. Esta Ley fue derogada por la Ley 16/1985, de 25 de junio, del Patrimonio Histórico Español (art. 20.1).

62 En desarrollo de lo prescrito en el artículo 46 de la Constitución Española, el Estatuto de Autonomía para Andalucía, aprobado mediante Ley Orgánica 2/2007 de 19 de marzo, establece en su artículo 10.3.3. ${ }^{\circ}$ que la Comunidad Autónoma ejercerá sus poderes con el objetivo básico del afianzamiento de la conciencia de identidad y cultura andaluza a través del conocimiento, investigación y difusión del patrimonio histórico, antropológico y lingüístico. Para ello, el artículo 37.1.18. ${ }^{\circ}$ preceptúa que se orientarán las políticas públicas a garantizar y asegurar dicho objetivo básico mediante la aplicación efectiva, como principio rector, de la conservación y puesta en valor del patrimonio cultural, histórico y artístico de Andalucía; estableciendo a su vez el artículo $68.3 .1 .^{\circ}$ que la Comunidad Autónoma tiene competencia exclusiva sobre protección del patrimonio histórico, artístico, monumental, arqueológico y científico, sin perjuicio de lo que dispone el artículo 149.1.28. ${ }^{a}$ de la Constitución. 
Recordemos que la declaración de un bien de interés cultural determina, además, su inclusión en el Catálogo General del Patrimonio Histórico Andaluz ${ }^{63}$. Si la declaración de interés cultural es pues el procedimiento que en el ámbito de la Ley estatal determina la integración de un bien en el Patrimonio Histórico y su sometimiento, por consiguiente, a un especial régimen de tutela, para la Ley de Patrimonio Histórico de Andalucía lo es la catalogación.

También la legislación estatal, atinente al entorno, asevera que un inmueble declarado Bien de Interés Cultural es inseparable de su entorno ${ }^{64}$ y por ello con la declaración se ha de delimitar dicho entorno ${ }^{65}$, siendo ello evidente, en cuanto al área afectada, en el supuesto de las declaraciones de los Conjuntos históricos. Por su parte, la normativa de Patrimonio Histórico de Andalucía adopta una posición sobre el entorno de los bienes inscritos como de interés cultural, acotándolo y matizando que "estará formado por aquellos inmuebles y espacios cuya alteración pudiera afectar a los valores propios del bien de que se trate, a su contemplación, apreciación o estudio, pudiendo estar constituido tanto por los inmuebles colindantes inmediatos, como por los no colindantes o alejados" ${ }^{66}$, estando sometidas a autorización toda actuación que se realice en dicho entorno. Y se añaden unas prohibiciones como las de "toda construcción que altere el carácter de los inmuebles inscritos como Bien de Interés Cultural o perturbe su contemplación"

Es de resaltar, además, que la protección del Patrimonio Histórico comprende también su defensa frente a lo que se ha dado en llamar "contaminación visual o perceptiva"68. Así se entiende por "contaminación visual o perceptiva" "aquella intervención, uso o acción en el bien o su entorno de protección que degrade los valores de un bien inmueble integrante del Patrimonio Histórico y toda interferencia que impida o distorsione su contemplación" ordena el que por los instrumentos de planificación urbanística se adopten medidas que eviten su contaminación visual o perceptiva, y dentro de ellas aquéllas que por su altura puedan perturbar su percepción ${ }^{70}$.

\section{LAS NORMAS DE DIRECTA APLICACIÓN EN EL URBANISMO (EL ENTORNO, LA PERSPECTIVA Y EL PAISAJE URBANO HISTÓRICO)}

Nuestro ordenamiento jurídico, en contra de lo que se expone en otros estudios, sí que acoge los paradigmas del paisaje urbano histórico y del entorno. En tal sentir baste con acudir, entre otras, a las "normas de directa aplicación" urbanísticas. Así, a nivel estatal, como norma de aplicación directa, expone el artículo 10.2 del Real Decreto Legislativo núm. $2 / 2008$, de 20 de junio, por el que se aprueba el texto refundido de la Ley de suelo71, dentro de los criterios básicos de utilización del suelo, lo siguiente: "Las instalaciones, construcciones y edificaciones habrán de adaptarse, en lo básico, al ambiente en que estuvieran situadas, y a tal efecto, ... en las perspectivas que ofrezcan los conjuntos urbanos de características histórico-artísticas, típicos o tradicionales, y en las inmediaciones de las carreteras y caminos de trayecto pintoresco, no se permitirá que la situación, masa, altura de los edificios, muros y cierres, o la instalación de otros elementos, limite el campo visual para contemplar las bellezas naturales, rompa la armonía del paisaje o desfigure la perspectiva propia del mismo"72.

Por su parte, en nuestra legislación urbanística autonómica73 se prescribe que "los actos de construcción o edificación e instalación que se realicen en terrenos adscribibles a la clase de suelo urbano, pero que no cuenten con instrumento de planeamiento, deberán observar las siguientes reglas: [... ] 2 $2^{a}$ ) Presentar características tipológicas y estéticas adecuadas a su integración en el entorno, en particular cuando existan en éste edificios de valor arquitectónico o patrimonial histórico"74. Si bien lo analizaremos en el contexto que impone la legislación estatal.

63 Ex art. 8 del Decreto núm. 19/1995, de 7-2-1995 (BO. Junta de Andalucia 17-3-1995, núm. 43, [pág. 2419]), por el que se Aprueba el Reglamento de Protección y Fomento del Patrimonio Histórico de Andalucía. Vid también el Reglamento de Organización Administrativa del Patrimonio Histórico de Andalucía, aprobado por Decreto 4/1993, de 26 de enero (declarado vigente por la Disposición derogatoria única de la Ley 14/2007, de 26 de noviembre, del Patrimonio Histórico de Andalucía), que en su artículo 2, atribuye a la Consejería de Cultura la competencia en la formulación, seguimiento y ejecución de la política andaluza en materia de Bienes Culturales, referida a la tutela, enriquecimiento y difusión del Patrimonio Histórico Andaluz.

64 Art. 18 de la Ley 16/1985 del 25 de junio de 1985, del Patrimonio Histórico Español.

65 Vid art. 11.2 de la Ley 16/1985 del 25 de junio de 1985. Vid asimismo art. 12.1 del Real Decreto 111/1986, de 10 de enero, de desarrollo parcial de la Ley 16/1985, de 25 de junio, del Patrimonio Histórico Español.

66 Ex art. 28.1 de la Ley 14/2007, de 26 de noviembre, de Patrimonio Histórico de Andalucía.

67 Ex art. 33.2 de la Ley 14/2007, de 26 de noviembre, de Patrimonio Histórico de Andalucía.

68 Vid epígrafe II $^{\circ}$ de la Exposición de Motivos de la Ley 14/2007, de 26 de noviembre, de Patrimonio Histórico de Andalucía. Añadiendo que «El impacto que producen sobre nuestro patrimonio determinados elementos e instalaciones exige conjugar las demandas de las tecnologías que inciden en nuestra vida diaria con la preservación de la calidad ambiental, siendo necesario para ello coordinar la actuación de las diferentes Administraciones Públicas».

69 Ex art. 19.1 de la Ley 14/2007, de 26 de noviembre, de Patrimonio Histórico de Andalucía.

70 Ex art. 19.2.a) de la Ley 14/2007, de 26 de noviembre, de Patrimonio Histórico de Andalucía. Vid. también la Disposición transitoria tercera que versa sobre la Descontaminación visual.

71 En lo sucesivo TRLS/08.

72 Antiguo artículo 138,b) TRLS/92.

73 Ley núm. 7/2002, de 17 de diciembre, de Ordenación Urbanística de Andalucía (en adelante LOUA).

74 Ex art. 57.2, regla $2^{\text {a LOUA. }}$ 


\section{A) Breve reseña histórica de las mismas}

Ante todo hemos de citar cómo desde el año 1926 en España se va concibiendo la necesidad de protección del patrimonio cultural. En efecto, tenemos que evocar el Real Decreto-Ley de 9 agosto de 1926 (relativo al tesoro artístico arqueológico nacional), el cual en su artículo 2 se exponía que formarán parte del Tesoro artístico nacional, además de otros bienes, "las edificaciones o conjuntos de ellas, sitios y lugares de reconocida y peculiar belleza, cuya protección y conservación sean necesarias para mantener el aspecto típico, artístico y pintoresco característico de España, siempre que así se haya declarado o en lo sucesivo se declare por el Ministerio de Instrucción pública y Bellas Artes", decretándose "de utilidad pública la conservación, protección y custodia de los monumentos arquitectónicos que forman parte del Tesoro histórico-artístico de la Nación"75, adscribiéndose al "suelo de la Nación"76 y considerándose como supuesto de expropiación (por "causa de utilidad pública") "los edificios que impidan la contemplación o dañen a un monumento del Tesoro artístico nacional, los adosados a murallas, torreones, etc., así como los rústicos o urbanos enclavados en recintos del Estado que pertenezcan al Tesoro artístico nacional"77.

Los primeros escarceos internacionales en aras de la tutela del Patrimonio cultural se prodigaron años más tarde ${ }^{78}$. Por su parte, los antecedentes mediatos de las normas de aplicación directa, en nuestro país, florecen en los artículos 59 y 60 de la Ley de 12 de mayo de 1956, de Régimen del suelo y ordenación urbana, que hacían referencia a la prohibición de levantar construcciones en lugares próximos a las carreteras de nuevo trazado (art. 59) y a la adecuación al entorno (art. 60).

Será con la reforma de la Ley del Suelo de 1956, operada el 2 de mayo de 1975, y el subsiguiente Texto Refundido de 9 de abril de 197679, cuando se amplían tenuemente dichas normas de directa aplicación.

Una sugerente novedad proviene del acrecentamiento del objeto que se opera desde el párrafo "b)" del art. 73 del TRLS/76, lo que se evidencia con la supresión del adverbio "excesivamente" "limiten excesivamente el campo visual"), introduciendo, en su ámbito de aplicación, nuevos supuestos a los que vincula, y abarcando un nuevo concepto limitativo, cual es el soslayar no sólo que se confine el campo visual o se rompa la armonía del paisaje, sino que se deforme ("desfigurar") "la perspectiva propia del mismo".

Otra mejora lo constituye el art. 74 según el cual mientras no exista Plan o Norma que lo autorice "no podrá edificarse con una altura superior a tres plantas", sin perjuicio de las demás limitaciones que sean aplicables. Y cuando se trate de "solares enclavados en núcleos o manzanas edificados en más de sus dos terceras partes, los Ayuntamientos podrán autorizar alturas que alcancen la media de los edificios ya construidos" ${ }^{\prime 0}$. Ya con el Reglamento de Planeamiento ${ }^{81}$, se reúnen las normas de aplicación directa en un mismo precepto, con el siguiente tenor:

“1. Solamente podrán levantarse construcciones en lugares próximos a las vías de comunicación de acuerdo con lo que, además de lo especificado en la Ley del Suelo, establezca la legislación específica aplicable.

2. Las construcciones habrán de adaptarse, en lo básico, al ambiente en que estuvieran situadas, y a tal efecto:

a) Las construcciones en lugares inmediatos o que formen parte de un grupo de edificios de carácter artístico, histórico, arqueológico, típico o tradicional, habrán de armonizar con el mismo o cuando, sin existir conjunto de edificios, hubiera alguno de gran importancia o calidad de los caracteres indicados.

b) En los lugares de paisaje abierto y natural, sea rural o marítimo, o en las perspectivas que ofrezcan los conjuntos urbanos de características histórico-artísticas, típicos o tradicionales y en las inmediaciones de las carreteras y caminos de trayecto pintoresco, no se permitirá que la situación, masa, altura

75 Artículo 7 del Real Decreto-ley de 9 agosto de 1926.

76 Artículo 8 del Real Decreto-ley de 9 agosto de 1926.

77 Ex art. 12, párrafo $3^{\circ}$, del Real Decreto-ley de 9 agosto de 1926.

78 Vid, por ejemplo, la Carta de Atenas de la Oficina Internacional de Museos (1931), el Informe sobre defensa y puesta en valor ("valorización") de los sitios y de los conjuntos histórico-artísticos (Ludwig Weis; aprobado por el Consejo de Europa en 1963), la Carta Internacional sobre la Conservación y Restauración de Monumentos y Sitios Histórico-Artísticos (Carta de Venecia, 1964), la Declaración de Praga (octubre de 1971), la Carta del Restauro (1972, mismo año de la Convención para la Protección del Patrimonio Mundial Cultural y Natural, París -UNESCO-), la Carta europea del patrimonio arquitectónico (1975), etc.

79 Real Decreto 1346/1976, de 9 abril, por el que se aprueba el Texto Refundido de la Ley Sobre Régimen del Suelo y Ordenación Urbana. Vid principalmente arts. 72 y 73. Al confrontar el texto de 1976 y el del primitivo art. 60 de 1956 se advertirá que, de un lado, ha desaparecido la locución de que el ambiente al que deben adaptarse las construcciones sea el "ambiente estético de la localidad o sector para que no desentonen", con lo que se amplía la operatividad de precepto con la dicción contenida en el TRLS/76. Por su parte, en el apartado a) se transcribe lo mismo que los predecesores apartados a) y b) del art. 60 de la LS/56.

80 El art. 99 del Reglamento de Planeamiento (Real Decreto 2159/1978, de 23 de Junio, por el que se aprueba el Reglamento de Planeamiento para el Desarrollo y Aplicación de la Ley sobre Régimen del Suelo y Ordenación Urbana) precisa la manera de medir las tres plantas y la altura media de los edificios.

81 Real Decreto 2159/1978, de 23 de Junio. 
de los edificios, muros y cierres, o la instalación de otros elementos, limite el campo visual para contemplar las bellezas naturales, rompa armonía del paisaje o la perspectiva propia del mismo.

\section{Las limitaciones a que se refieren los dos números anteriores tendrán aplicación en todo caso, existan o} no aprobados Planes de ordenación o normas complementarias y subsidiarias de planeamiento" 82.

Como puede observarse, lo más sobresaliente de esta norma del Reglamento de Planeamiento, es que se añadía ese párrafo tercero, en cuya virtud, las restricciones, limitaciones o condiciones preceptivas de aplicación directa precitadas han de ser utilizadas y previstas en todo momento (siempre), por cuanto "tendrán aplicación en todo caso, existan o no aprobados Planes de Ordenación”, enfatizando así su propensión imperativa, necesaria, forzosa, ineludible y de inmediata vinculatoriedad.

EI TRLS/1992 mantuvo las reglas de los arts. 73 y 74 de 1976, si bien, la STC 61/1997, de 20 marzo (RTC 1997, 61) declaró la inconstitucionalidad de todos los preceptos de carácter supletorio, lo que supuso la anulación del art. 139 y de la letra a) del art. 138 subsistiendo con carácter básico, no obstante, el tenor de la letra b) del precitado art. 138, y sin sufrir retoques por la Ley 6/1998, de 13 de abril. Ahora bien, los mandatos quedaban prácticamente incólumes, con carácter supletorio, a la regulación que contuviesen las legislaciones autonómicas.

\section{B) Concepto y naturaleza jurídica}

Las "normas de aplicación directa", como su propio tratamiento revela, son disposiciones legales sustantivas de ordenación que tienen vocación de aplicabilidad y obligatoriedad (o vinculatoriedad) absoluta, rotunda e inmediata $^{83}$, haya o no haya Plan, de manera que, en principio y por principio, prevalecen sobre las determinaciones concretas de los planes, entre otras cosas por unos básicos principios de legalidad y de jerarquía normativa (norma legal, frente a norma con rango reglamentario ${ }^{84}$. Si bien esta tajante dicción ha ido sufriendo una mutación en la labor exegética jurisprudencial, puesto que previamente se entendía que la preexistencia de un instrumento de planeamiento suponía un dato notable a tener presente, puesto que en su tramitación habría concurrido la participación de diferentes organismos sectoriales a los que está encomendada primariamente la defensa de aquellos mismos valores del patrimonio natural y cultural en general ${ }^{85}$, o que estuviese así reconocido, el terreno en cuestión, como perteneciente a un ámbito espacial más extenso objeto de especial protección ${ }^{86}$.

Concepto que no es una apreciación subjetiva de lo estético, sino la necesidad de adecuar proporcionalmente lo construido al entorno en el que se construye ${ }^{87}$.

Las “normas de aplicación directa" son preceptos emanados de Ley, y al mismo tiempo paradigmas y directrices específicas de directa, inmediata, rigurosa, preceptiva, sólida y prioritaria utilización, por lo que son y han de ser de inexcusable observancia, con independencia de que existan o no planes, siendo "un texto legal que se impone al planificador" 88 , pues así se deduce del tenor literal del precepto analizado cuando, dogmatiza de modo rotundo “... no se permitirá..." ${ }^{89}$, con el mismo objeto de la "Normativa de carácter general de Protección del Patrimonio artístico"90. Por ello se puede sostener que las "normas de aplicación directa" se anteponen tanto a la esfera voluntarista de la Administración, como del planificador, ostentando vinculatoriedad propia.

82 Artículo 98 del Reglamento de Planeamiento.

83 Directamente obligatorias como recogió la sentencia de 27 de febrero de 1976 (RJ 1976, 1484).

84 Expone sobre el particular la Sentencia del Tribunal Supremo (Sala de lo Contencioso-Administrativo, Sección $5^{\mathrm{a}}$ ) de 21 noviembre 2000 (RJ/2000|10267) que "Es abrumadoramente reiterativa, la doctrina de este Tribunal -sentencias de 24 de octubre y 8 de noviembre de 1990 (RJ 1990, 8329 y 8820), 16 de junio de 1993 (RJ 1993, 4884), 10 y 12 de abril de 1996 (RJ 1996, 2940 y 3259), entre muchas otrasde que esos preceptos, se aplican en todo caso, existan o no Planes de Ordenación o Normas Complementarias o Subsidiarias de Planeamiento y son de inexcusable observancia”. Ver también la sentencia del Tribunal Supremo de fecha 23 de octubre de 2002 (RJ|2002|10062) cuando asevera que: "Que el artículo 138-b) del TR-92 es aplicable directamente, haya o no haya Plan y guarde silencio o diga lo contrario, no cabe duda. Así lo expresa el artículo 98.3 del Reglamento de Planeamiento, que se limita a precisar a la Ley”.

85 Por ejemplo, vid SSTS de 16 de mayo de 1995, Ar. 3803, Ponente Excmo. Sr. Barrio Iglesias; 7 de diciembre de 1995, Ar. 8995, Ponente Excmo. Sr. Yagüe Gil.

86 Vgr. STS de 24 de febrero de 1992, Ar. 2791, Ponente Excmo. Sr. Rodríguez-Zapata Pérez.

87 González Varas, “Urbanismo y ordenación del territorio”, Aranzadi, 2005, pág. 368.

88 Vid sentencias del TS de 10 de abril de 1996 (RJ)1996|2940; Fto. Jur. $5^{\circ}$ ) y de 16 de junio de 1993 (RJ 1993, 4884).

89 Vid sentencia del Tribunal Superior de Justicia de Castilla y León, Burgos (Sala de lo Contencioso-Administrativo, Sección $1^{\mathrm{a}}$ ), núm. 79/2006, de 10 febrero (JUR|2006|111840).

90 Tal y como sostiene la Sentencia del Tribunal Superior de Justicia de Castilla y León, Burgos (Sala de lo Contencioso-Administrativo, Sección $1^{\mathrm{a}}$ ), núm. 79/2006, de 10 febrero (JUR|2006|111840), en su Fto. Jur. $5^{\circ}$. La Sentencia del Tribunal Superior de Justicia Andalucía, Sevilla, (Sala de lo ContenciosoAdministrativo, Sección 2a), de 4 octubre 2005 (RJCA 2006|254; siendo Ponente: Ilmo. Sr. D. José Antonio Montero Fernández; FJ $9^{\circ}$ ) llega a decir que se trata de un precepto que, adaptándose a la correspondiente materia: "suele ser habitual en la normativa de especial protección, como patrimonio histórico o espacios naturales". 
Además, evoquemos que siendo, como es, legislación básica sobre protección del medio ambiente, hemos de reconocer la competencia exclusiva que tiene asignada el Estado ${ }^{91}$, sin perjuicio de las facultades de las Comunidades Autónomas de poder implantar normas adicionales en esta materia de protección ${ }^{92}$, de ahí que no fuese declarado inconstitucional ${ }^{93}$ y subsistiese vigente.

Del mismo modo, destaquemos que estas "normas de aplicación directa" encierran conceptos jurídicos indeterminados aunque de naturaleza reglada ${ }^{94}$, si bien en su apreciación se introduce, con frecuencia, un porcentaje de discrecionalidad, en razón del halo de dificultad que caracteriza el espacio de incertidumbre que media entre las zonas de certeza positiva y negativa ${ }^{95}$.

Ahora bien, tales conceptos jurídicos indeterminados han de ser interpretados, de modo muy especial, conforme a la realidad social del tiempo en que han de ser aplicados ${ }^{96}$, siendo de advertir que la realidad social coetánea, refleja una muy aguda entrega e interés en vigilar, cuidar, conservar, defender y proteger las perspectivas naturales y la armonía del medio ambiente, respecto de las construcciones, instalaciones o edificaciones, y recuerdos históricos legados por nuestros antepasados ${ }^{97}$.

En definitiva, concurriendo en la realidad que se analice el supuesto de hecho previsto en la norma ("entorno a salvaguardar"), la circunstancia externa modificadora del mismo ("contexto extrínseco"), y el "efecto prohibido" legalmente, procederá la aplicación automática del precepto98, cualquiera que sea la regulación que sobre los terrenos prevea el planeamiento. De donde se denota la automaticidad al converger la meritada trilogía.

\section{C) Características ingénitas de las "normas de aplicación directas" estatales}

Podemos decir que las características definitorias de estas normas de aplicación directa estatales, son en síntesis las siguientes: ción ${ }^{99}$.

$1^{\circ}$ ) El espíritu de las "normas de aplicación directa" parece recogido por el artículo 45 de nuestra Constitu-

$2^{\circ}$ ) Son mandatos básicos y primarios estatales que el legislador autonómico puede complementar, de aplicación ante cualquier situación jurídica ${ }^{100}$, clase o categoría de suelo, dado el carácter primordial con que resulta regulado por el legislador estatal ${ }^{101}$. Por lo que este paradigma se impone con independencia de lo que se prevea por el legislador autonómico ${ }^{102}$.

$3^{\circ}$ ) Se aplican en todo caso, existan o no Planes de Ordenación, siendo normas con rango legal, que contienen determinaciones sustantivas imperativas de absoluta, rotunda y directa vinculatoriedad y aplicación ${ }^{103}$, por lo que prevalecen ante determinaciones de Plan.

91 Ex artículo 149.23 de la Constitución.

92 Así refrendado por nuestra jurisprudencia, como por ejemplo en Sentencia del Tribunal Supremo (Sala de lo Contencioso-Administrativo, Sección $5^{\text {a }}$ ) de 21 noviembre 2000 (RJ|2000|10267) cuando expresamente previene que "La observancia, pues, del precepto del artículo 138 b) de la Ley del Suelo de 22 de junio de 1992 - como el artículo 73 de la Ley de 1976-, con carácter de legislación básica, según la Disposición final única del Texto legal de 1992, en virtud de lo previsto en el artículo 149.23 de la Constitución (RCL 1978, 2836 y ApNDL 2875), el Estado tiene competencia exclusiva respecto de la legislación básica sobre protección del medio ambiente, sin perjuicio de las facultades de las Comunidades Autónomas de establecer normas adicionales de protección".

93 No se vio afectado por la declaración de inconstitucionalidad por la sentencia del Tribunal Constitucional 61/1997 (RTC 1997, 61). Asimismo, lo evoca la sentencia del Tribunal Supremo de fecha 23 de octubre de 2002 (RJ/2002|10062; Fto. Jur. 6”) como "precepto no declarado anticonstitucional".

94 En la ya indicada Sentencia del Tribunal Supremo (Sala de lo Contencioso-Administrativo, Sección $5^{\mathrm{a}}$ ) de 21 noviembre 2000 (RJ|2000|10267) textualmente se postula que ““"El artículo 138.b) citado protege fundamentalmente las perspectivas, los campos visuales de contemplación de las bellezas naturales o históricamente monumentales, la no rotura de la armonía del paisaje o la desfiguración de las perspectivas propias del mismo, que encierran conceptos jurídicos indeterminados, pero de indudable naturaleza reglada".

95 Vid sentencias del TS de 31 de diciembre 1988 [RJ 1988, 10293], 8 de noviembre de 1990 y 12 de abril de 1996), todas ellas recordadas por la sentencia del TS de 21 noviembre 2000 (RJ|2000|10267).

96 Ex artículo 3 del Código Civil.

97 En tal sentir, igualmente, vid sentencia del TS de 21 noviembre 2000 (RJ|2000|10267)

98 Artículo 10.2 del TRLS/08. Con tal posición vid sentencia del Tribunal Superior de Justicia de Castilla y León, Burgos (Sala de lo Contencioso-Administrativo, Sección $1^{\mathrm{a}}$ ), núm. 79/2006, de 10 febrero (JUR|2006|111840).

99 En tal sentir, vid STS de 12 abril 1996 (RJ 1996, 3259).

100 Según las reconocidas por el TRLS/08.

101 Evoquemos el brocardo de "ubi lex non distinguit, nec nos distinguere debemus", siendo un principio general del derecho, según lo tilda la sentencia del TS de 28 de mayo de 1996 -Sala $3^{\text {a }}$, Sección $3^{\text {a }}$ (RJ 1996/4245).

102 Recuérdese que se trata de legislación básica sobre protección del medio ambiente, competencia exclusiva del Estado (ex artículo 149.23 de la CE), pudiendo las Comunidades Autónomas establecer normas adicionales en esta materia de protección [Vid, por ejemplo, Sentencia del Tribunal Supremo (Sala de lo Contencioso-Administrativo, Sección $5^{\text {a }}$ ) de 21 noviembre 2000 (RJ/2000|10267)].

103 De forma parecida se citan por el art. 108 del Decreto Legislativo núm. 1/2004, de 22 de abril, por el que se aprueba el texto refundido de las disposiciones legales vigentes en materia de ordenación del territorio y urbanismo del Principado de Asturias ("determinaciones legales sustantivas de directa aplicación”). 
$4^{\circ}$ ) Son normas de ineludible acatamiento, que se anteponen e imponen al planificador (haya o no Plan ${ }^{104}$ ), a la Administración y a los administrados, siendo de inexcusable observancia.

$5^{\circ}$ ) Su aplicación es directa, por lo que no precisa de desarrollo por otra disposición o acto ${ }^{105}$.

$6^{\circ}$ ) La Ley lo que trata de evitar es que se levanten construcciones que no armonicen con las características de un conjunto de edificios, o de singular relevancia, merecedores de una salvaguarda y de una situación destacada, sin que sea necesario esa pertenencia al casco antiguo o a que previamente tengan que estar catalogados, porque la Ley no distingue ${ }^{106}$.

$7^{\circ}$ ) Por disposición legal se fija el ámbito espacial en que puede producirse la desarmonía con tales lugares, paisajes o construcciones a proteger ("entorno a salvaguardar").

$8^{\circ}$ ) Estas "normas de aplicación directa" cobijan conceptos jurídicos indeterminados, aunque de indudable naturaleza reglada ${ }^{107}$, que comprenden la trilogía de un "entorno a salvaguardar", lo que hemos denominado como "contexto extrínseco" y el "efecto prohibido" legalmente.

$9^{\circ}$ ) Son máximas que operan automáticamente ante la concurrencia de la enunciada trilogía ("entorno a salvaguardar", "contexto extrínseco" y "efecto prohibido"), con independencia de la regulación urbanística y/o territorial.

$10^{\circ}$ ) Exhorta motivación adecuada, prueba suficiente y prudencia ${ }^{108}$.

D) La estrategia de paisaje de Andalucía (2012)

El 6 de marzo de 2012, el Consejo de Gobierno de la Junta de Andalucía adopta el Acuerdo de aprobar la Estrategia de Paisaje de Andalucía. Esta Estrategia se fundamenta en el desarrollo de siete objetivos de calidad paisajística ${ }^{109}$ que requieren de la actuación concertada de varias Consejerías y que implican a los tres ejes de intervención establecidos en el Convenio Europeo: la protección, gestión y ordenación de los paisajes. Y de entre esos siete objetivos destacamos ahora dos: impulsar la recuperación y mejora paisajística del patrimonio cultural ${ }^{110}$, y cualificar los espacios urbanos.

Asimismo, hemos de resaltar que la Estrategia de Paisaje de Andalucía pone un énfasis especial en el paisaje como un activo para el desarrollo sostenible y la competitividad de Andalucía, capaz de contribuir a la creación de renta y empleo. Enfoca la calidad del paisaje como un recurso esencial para el desarrollo turístico, un sector estratégico de la economía andaluza, y que progresivamente había ido teniendo acogida en diversos textos normativos autonómicos ${ }^{111}$.

De todas las líneas estratégicas destacaremos la 21 y la 22. La Línea estratégica 21 versa sobre los Valores culturales del paisaje, y la acción paisajística en los entornos de los BIC, se orienta a la descontaminación visual, a la integración paisajística y al mantenimiento de los valores culturales, a la mejora del acceso físico y visual, etc.

104 Al menos, en principio, esta ha sido la tónica general y jurisprudencial.

105 “De tal modo que cualquier disposición o acto administrativo (plan, general o su ejecución, licencia, permiso, etc.) que estuviesen en manifiesta contradicción con tales preceptos, aunque aquella disposición o acto se ajustasen al planeamiento vigente y no infringiesen la concreta norma urbana aplicable, serían anulables si estuvieran en contradicción con esos artículos, que protegen la armonía apreciable o que emana de un grupo de edificaciones de carácter histórico, arqueológico, artístico o meramente típico o tradicional; o también respecto de edificios aislados que reúnan esas características" (STS de 12 abril 1996 [RJ 1996, 3259]).

106 Vid STS de 31 marzo 1989, (RJ 1989, 2444), que añade en su Fto. Jur. $4^{\circ}$ que “(... ) ni es necesaria una declaración previa de conjunto histórico-artístico -SS. 6 julio y 30 junio 1982-; y aunque el edificio o conjunto de edificios en que concurran los valores que la norma trata de proteger (...) no se encuentren incluidos en los correspondientes Catálogos, pues de no ser así carecería de sentido que los mentados preceptos precisen con todo detalle los caracteres que deben reunir aquéllos para que las construcciones en lugares inmediatos a los mismos deban adaptarse, en lo básico al ambiente en que estuviesen situados haciendo referencias a edificios de carácter artístico, histórico, arqueológico, típico o tradicional -SS. 20 abril y 11 febrero $1985-"$ ".

107 Aunque en su apreciación se introduzca con frecuencia un tanto de discrecionalidad o subjetivismo, en razón del halo de dificultad que caracteriza el espacio de incertidumbre que media entre las zonas de certeza positiva y negativa. En tal sentir, vid, por ejemplo, Sentencia del TS de 31 de diciembre 1988 (RJ 1988, 10293)

108 La trasgresión del “entorno a salvaguardar" (con la presencia de los otros dos elementos) requiere de cumplida prueba, clara y contundente de los elementos fácticos que en cada caso puedan integrarse en los supuestos de idéntica naturaleza que el precepto legal contiene, siendo necesario mayor rigor y precisión de la misma si se pretende sostener en contra de expresa dicción de instrumento de planeamiento.

109 Estos siete objetivos consisten en: impulsar la recuperación y mejora paisajística del patrimonio natural, impulsar la recuperación y mejora paisajística del patrimonio cultural, cualificar los espacios urbanos, cualificar los paisajes asociados a actividades productivas, cualificar las infraestructuras de transporte, energía y telecomunicaciones, implementar instrumentos de gobernanza paisajística y potenciar la sensibilización, la educación y la formación en materia de paisaje.

110 El Objetivo $2^{\circ}$ es precisamente el impulsar la recuperación y mejora paisajística del patrimonio cultural, enfatizándose que "el patrimonio cultural no sólo debe ser apreciado en las mejores condiciones posibles, sino que constituye, en sí mismo, un valor añadido que realza la calidad de los paisajes. Ello requiere potenciar su dimensión paisajística mediante la aplicación y desarrollo de los instrumentos existentes, pero también avanzar progresivamente hacia un marco innovador en la política de patrimonio cultural".

111 Todas las recogidas en el Anexo II de la Estrategia. 
La línea estratégica 22 versa sobre los Paisajes de interés cultural (PIC), prevé una guía para la formulación de objetivos de calidad paisajística en los PIC, la ordenación paisajística de los mismos (orientada a la recuperación de paisajes degradados), un Registro de ellos o el establecimiento de Directrices, recomendaciones y planes directores de los Paisajes Históricos Urbanos.

\section{LA TORRE PELLI EN SEVILLA}

Dado que esta construcción no es el objeto de este estudio, haremos una muy brevísima alusión a ella, y sólo en lo concerniente a su posible implicación con esa tildada posible "amenaza" de los monumentos sevillanos inscritos en la Lista de Patrimonio Mundial de la UNESCO.

No obstante, debemos partir de su encuadre urbanístico, legitimador de su implantación. Así mencionar que la Revisión del Plan General de Ordenación Urbanística (PGOU) de Sevilla"12 recoge las determinaciones del "ARIDT-10 Puerto Triana", entre las fichas de la clase de "Suelo Urbano" y categorizado como "No consolidado" a desarrollar mediante Plan Especial y gestionar por compensación, para una superficie total de 180.558 metros cuadrados $^{133}$. Igualmente se asignan usos y edificabilidades ${ }^{14}$, previéndose su programación para el primer cuatrienio.

Es de significar que tanto el Plan Especial (PERI)"15, como el proyecto de urbanización ${ }^{116}$, se aprueban definitivamente ${ }^{17}$, sin que se hubiesen producido Alegaciones en el decurso del preceptivo trámite de información pública"18.

El 16/07/2007 se obtiene licencia para movimientos de tierras y ejecución de pantallas en el perímetro de la parcela"19, y el 17/09/2008 se otorga licencia del conjunto edificatorio.

Además, por la Administración autonómica se declara la innecesariedad de la evaluación del impacto ambiental del Proyecto ${ }^{120}$.

Es de resaltar que, asimismo, se emite informe por parte del Ministerio de Cultura que examina la normativa que pudiera ser aplicable al caso, concluyendo que el complejo donde se localiza la torre está evidentemente fuera del conjunto histórico declarado por la UNESCO, estimando compatible el proyecto con el PGOU de 2006, y precisa que el proceso urbanístico aplicado en la concesión de la licencia es conforme a la normativa de aplicación. Del mismo modo, concluye respecto a la posible afección visual, que no hay tal desde el entorno peatonal inmediato a los edificios declarados Bienes de Patrimonio Mundial por la UNESCO en 1987 (Catedral, Alcázar y Archivo de Indias).

\section{LA INEXISTENTE AFECCIÓN VISUAL DE LA TORRE PELLI}

Existe un exhaustivo estudio elaborado por "Miembros del Grupo de Investigación Composición, Arquitectura y Medio Ambiente (CARMA), adscritos al Departamento de Historia, Teoría y Composición Arquitectónicas de la Universidad de Sevilla, considerando que el Área de Conocimiento propia del Departamento y del Grupo es plenamente competente para el desarrollo de un estudio en materias de arquitectura y patrimonio" ${ }^{121}$. Y para no

112 Aprobada mediante Resolución de la Consejera de Obras Públicas y Transportes (Junta de Andalucía) de 19 de julio de 2006 (Texto Refundido, Resolución de 9 de octubre de 2007).

113 La Ficha correspondiente al “ARI-DT-10 Puerto Triana” determina el área de reparto T-09/UR, el aprovechamiento medio 0,4819 UA/ $\mathrm{m} 2$, la superficie total $180.558 \mathrm{~m} 2$; la superficie de suelo con aprovechamiento: $136.703 \mathrm{~m} 2$ y el suelo público asociado: $43.855 \mathrm{~m} 2$.

114 Distribuyéndose $68.000 \mathrm{~m} 2 \mathrm{t}$ para servicios terciarios, de los cuales $48.000 \mathrm{~m} 2 \mathrm{t}$ pueden destinarse a Gran Superficie Comercial, 84.064 m2 de Espacios Libres y $12.592 \mathrm{~m} 2$ de SIPS.

115 Redactado por la Gerencia de Urbanismo del Excmo. Ayuntamiento de Sevilla.

116 De las Manzanas SIPS1 y CT1 del PERIARI-DT-10 Puerto Triana.

117 El PERI: Por el Excmo. Ayuntamiento Pleno el 19 de abril de 2007 (BOP nº 144 de 23 de junio de 2007), y se registra con el n 8, de fecha 2 de mayo de 2007, en el Registro Municipal de Instrumentos Urbanísticos de Sevilla. El Proyecto de Urbanización se aprueba por la Junta de Gobierno de la Ciudad de Sevilla el 5 de diciembre de 2007 (BOP de 21 de mayo de 2010).

118 Destacamos, no obstante, que existe informe del Delegado Provincial de la Consejería de Cultura sobre el documento de aprobación inicial del Plan Especial de Reforma Interior Ari-DT-10 Puerto de Triana, se emite en 22 de febrero de 2006, con entrada en la Gerencia de Urbanismo en 7 de marzo de 2006, en sentido favorable.

119 Por Resolución del Sr. Gerente de la Gerencia de Urbanismo de Sevilla de fecha 16 de julio de 2007 se otorga a la entidad mercantil Puerto Triana, S.A. licencia para movimientos de tierras y ejecución de pantallas en el perímetro de la parcela sita en calle Inca Garcilaso, Centro Puerto Triana, de Sevilla. (Expte. 1122/07 del Servicio de Licencias Urbanísticas).

120 Resolución 17 de enero de 2011, del Delegado Provincial de Sevilla de la Consejería de Medio Ambiente de la Junta de Andalucía, competente en la materia, se "Declara No necesaria la evaluación del impacto ambiental del Proyecto de Urbanización de las Manzanas SIPS 1 y CT 1 de Puerto Triana correspondiente al Plan Especial del ARI-DT-10 Puerto Triana”.

121 "El área estudiada comprende los tres monumentos declarados patrimonio de la humanidad en 1987: La Catedral, el Archivo de Indias y Los Reales Alcázares". Y téngase bien presente que Sevilla es de topografía casi plana. Tras analizar qué debe entenderse por “afección visual” con cierto grado de objetividad, se toma una altura promediada de los ojos (1,75-180 m) y se examina el campo visual ("Denominamos campo visual al ángulo sólido formado por el semicono que parte desde el cristalino hacia el exterior y que se mide en estereorradianes"), estableciendo la correspondiente amplitud del (semiángulo) del mismo, matizando que cada entorno está determinado por la correspondiente amplitud del semiángulo de un cono imaginario que tuviese su eje coincidente con la línea recta que une el cristalino del ojo con el objetivo dela visión, para 
caer en el mismo error que se cometió con el Informe de ICOMOS del año 2008, sólo extractaré de él sus conclusiones, pues en absoluto tiene el que suscribe titulación ni conocimientos para opinar alegremente de esta cuestión.

Y tras el exhaustivo análisis concluyen lo siguiente: "Podemos resumir afirmando que la Torre Cajasol no es visible desde ningún punto de vista en el entorno de los monumentos Patrimonio Mundial, desde el que los propios monumentos sean visibles, por lo tanto no existe interferencia posible desde estos puntos de vista"122.

\section{EL PRINCIPIO DE SEGURIDAD JURÍDICA, Y SU RELACIÓN CON LOS PRINCIPIOS DE LEGALIDAD, DE BUENA FE Y DE CONFIANZA LEGÍTIMA}

La seguridad jurídica se ha venido describiendo, reconociendo y determinando como uno de los "fines del Derecho", pero a la vez como presupuesto, valor y pilar del Derecho y de la propia justicia. La justicia y la seguridad jurídica no son realidades antinómicas. "La Seguridad no es la Justicia. Es un valor que está fuera de la Justicia, pero al servicio de la Justicia. Es el valor adjetivo de la Justicia: "Prœeter Justitiam, sed pro Justitia"” ${ }^{23}$. Se debe subrayar la superioridad de los grandes principios y valores jurídicos -la libertad, la igualdad, la justicia, el pluralismo político, la dignidad de la persona, la seguridad jurídica, la buena fe... ${ }^{124}-$ sobre las normas concretas y contingentes. Son los primeros los que constituyen el fundamento mismo del orden jurídico-político del Estado de derecho e informan la totalidad del ordenamiento.

En términos generales, la seguridad jurídica supone la certeza que tienen los sujetos de que su situación jurídica no será alterada sino mediante procedimientos establecidos previamente y por causas tasadas, ligado a la previsibilidad de las conductas en sociedad. En efecto, los hombres precisamos saber en qué fiarnos, a qué atenernos ${ }^{125}$, conocer cuáles son las reglas del juego, las pautas que rigen la vida jurídica en concreto ${ }^{126}$. Esto es indispensable para que podamos ejercitar la observancia de nuestros deberes de justicia y de exigir que, a nuestro respecto, se observen también los deberes jurídicos que correspondan.

Hemos de recordar, por otra parte, que la "seguridad humana", en el ámbito internacional, es un concepto desarrollado por el Programa de Naciones Unidas en su informe sobre Desarrollo Humano de 1994, que incluye diferentes dimensiones, abarcando desde la seguridad en el ámbito público y en el ámbito privado, hasta la alimentaria, económica, educativa, sanitaria, ambiental, democrática y la propia seguridad jurídica ${ }^{127}$. No sorprende, por ende, que sea reconocida la seguridad jurídica como algo esencial a la vida política (su principio y su valor) y llegue a formularse cual derecho fundamental ${ }^{128}$.

así ver los campos dentro del cono visual. Además, "La trama urbana en la que se asientan los tres monumentos es la zona sur del casco antiguo de Sevilla,... Su morfología se caracteriza, a grandes rasgos, por una elevada colmatación del suelo disponible; el caserío se define por su frente de fachada y la profundidad edificable, mientras que las calles suelen ser estrechas, oscilando la mayoría entre los 3 y los 6 metros de anchura... El tejido urbano tiene un altura de edificación que oscila entre las 3 y las cuatro alturas (12-15 metros) en el caserío, siendo mayor en edificios singulares".

122 Llegándose a la misma conclusión de no afección visual que en el informe emitido por el Ministerio de Cultura.

123 Luño Peña, Enrique, Derecho Natural, ed. Hormiga de Oro, Barcelona, 1954, p. 219.

124 Ex arts. 1.1, 9,10.1... de la Constitución Española de 1978, art. 7 del Código Civil.

125 Nuestro Tribunal Constitucional ha señalado en su sentencia de 15 de marzo de 1990 (RTC 1990, 46) que "el legislador ha de perseguir la claridad, no la confusión [...]. Es relevante que los operadores jurídicos y los ciudadanos sepan a qué atenerse en la relación con la materia sobre la que la ley legisla [...]. Hay que buscar la certeza respecto a lo que es Derecho y no lo es y no provocar relaciones entre normas que den lugar a perplejidad respecto a la previsibilidad exigible al Derecho".

126 Ya decía Aristóteles, en el primer libro de la Retórica, que "corresponde a las leyes bien dispuestas determinarlo todo por sí, en cuanto sea posible, y dejar a los que juzgan lo menos posible” (Retórica, Bkk. 1.354 b; cfr. también: Política, Bkk. 1.287).

127 Este concepto coloca al ser humano como el centro de las acciones para reducir las amenazas que restringen el desarrollo de capacidades y el aprovechamiento de las oportunidades para el desarrollo.

128 Así, por ejemplo, vid, la Declaración de Virginia de 1776 que en su artículo $1^{\circ}$ se expone que los hombres poseen derechos innatos, entre ellos el relativo a los medios para buscar y conseguir la felicidad y la seguridad [happiness and safety] (The Virginia Declaration of Rights, 12-6-1776, art. 1": "That all men are by nature equally free and independent and have certain inherent rights, of which, when they enter into a state of society, they cannot, by any compact, deprive or divest their posterity; namely, the enjoyment of life and liberty, with the means of acquiring and possessing property, and pursuing and obtaining happiness and safety"). También vid la Declaración de la Independencia de los Estados Unidos de América, de 1776 (The Declaration of Independence of The United States of America, 4-7-1776: “...to institute new government, laying its foundation on such principles and organizing its powers in such form as to them shall seem most likely to effect their safety and happiness"), o la Declaración francesa de los Droits de l'Homme et du Citoyen (“Declaración de los Derechos del Hombre y del Ciudadano"), de agosto de 1789 (art. $2^{\circ}$ : "Le but de toute association politique est la conservation des droits naturels et imprescritibles de l'homme. Ces Droits sont la liberté, la propriété, la sûrété, et la résistance à l'opression"

- "El objeto de toda sociedad política es la conservación de los derechos naturales e imprescriptibles del hombre. Estos derechos son la libertad, la propiedad, la seguridad y la resistencia a la opresión”-), o la Declaración Universal de los Derechos Humanos, de la Organización de las Naciones Unidas, diciembre de 1948 (Declaración Universal de Derechos Humanos, 10-12-1948, art. $3^{\circ}$ : "Todo individuo tiene derecho a la vida, a la libertad y a la seguridad de su persona"). Igfualmente vid la Convención para la Salvaguarda de los Derechos del Hombre y de las Libertades Fundamentales (Convenio Europeo de Derechos Humanos) de noviembre de 1950 (Convention de sauvegarde des droits de l'homme et des libertés fondamentales, 4-11-1950, art. 50: "Toute personne a droit à la liberté et à la sûreté"), o el Pacto Internacional de Derechos Civiles y Políticos, de la Organización de las Naciones Unidas, en diciembre de 1966 (Pacto Internacional de Derechos Civiles e Políticos, 16-12-1966, art. 9: "Todo individuo tiene derecho a la libertad y a la seguridad personales"), etc. 
En la Encíclica Pacem in Terris, aludiendo a Pío XII, se hace referencia a la seguridad jurídica con estas palabras: "Del ordenamiento jurídico querido por Dios deriva el inalienable derecho del hombre a la seguridad jurídica y, con ello, a una esfera concreta de derecho, protegida contra todo ataque arbitrario" ${ }^{22}$.

El propio Tribunal de Justicia de la Unión Europea ${ }^{130}$ ha considerado que el instituto de la seguridad jurídica (al que otorga el rango de principio general del Derecho de la Unión ${ }^{131}$ ), exige que una normativa de la Unión permita a los interesados conocer con exactitud el alcance de las obligaciones que les impone. Así, los justiciables deben poder conocer, sin ambigüedad, sus derechos y obligaciones, y adoptar las medidas oportunas en consecuencia132. Son las reglas de juego, las pautas para saber a qué atenerse para una convivencia pacífica ${ }^{133}$.

En nuestro ordenamiento, el principio de seguridad jurídica aparece contemplado en el artículo 9.3 de la CE ${ }^{134}$, y según la doctrina del TC este principio implica la suma de certeza y legalidad, jerarquía y publicidad normativa, irretroactividad de lo no favorable ${ }^{135}$, interdicción de la arbitrariedad, equilibrada de tal suerte que permita promover, en el orden jurídico, la justicia y la igualdad en libertad, sin perjuicio del valor que por sí mismo tiene aquel principio $^{136}$. Es decir, la seguridad jurídica ha de entenderse como la certeza sobre el ordenamiento jurídico aplicable y los intereses jurídicamente tutelados, procurando "la claridad y no la confusión normativa" 137, y como "la expectativa razonablemente fundada del ciudadano en cuál ha de ser la actuación del poder en la aplicación del Derecho” 138.

En suma, sólo si en el Ordenamiento jurídico en que se insertan, y teniendo en cuenta las reglas de interpretación admisibles en Derecho, el contenido o las omisiones de un texto normativo produjeran confusión o dudas que generaran en sus destinatarios una incertidumbre razonablemente insuperable acerca de la conducta exigible para su cumplimiento o sobre la previsibilidad de sus efectos, podría concluirse que la norma infringe el principio de seguridad jurídica139.

La seguridad jurídica, por ende, se define e identifica con el conjunto de factores jurídicos que se instauran por un Estado para mantener su estabilidad y funcionamiento, no siendo sólo un concepto jurídico abstracto o un dogma, sino que su contenido abarca múltiples aspectos y momentos.

Connotaciones congénitas del principio de la seguridad jurídica podrían reconocerse en la cognoscibilidad, la previsibilidad ${ }^{140}$ y la confianza ${ }^{141}$. Por la primera (cognoscibilidad), los destinatarios de una norma obtendrían el conocimiento (certeza del derecho ${ }^{142}$ y en el derecho), de ahí el que se requiera la publicidad adecuada y formal de las normas, así como la claridad y un cierto halo de precisión de las mismas ${ }^{143}$ para resultar entendibles. Por la

129 Pacem in Terris, Carta Encíclica de su Santidad Juan XXIII, n. 27.

130 En lo sucesivo, TJCE.

131 Sentencia del TJCE de 14 septiembre 2010 (Gran Sala) [TJCE 2010, 275], Caso Akzo Nobel Chemicals y Akcros Chemicals/Comisión y otros ("Procede recordar que el principio de seguridad jurídica constituye un principio general del Derecho de la Unión que exige, en particular, que una normativa que entrañe consecuencias desfavorables para los particulares deba ser clara y precisa y su aplicación previsible para los justiciables (véanse las sentencias de 14 de abril de 2005 [TJCE 2005, 88], Bélgica/Comisión, C-110/03, Rec. p. I-2801, apartado 30 ; de 7 de junio de 2007 [TJCE 2007, 133], Britannia Alloys \& Chemicals/Comisión, C-76/06 P, Rec. p. I-4405, apartado 79, y de 14 de enero de 2010 [TJCE 2010, 8], Stadt Papenburg, C-226/08, Rec. p. 1-0000, apartado 45)"). Vid también Sentencia del TJUE de 18 noviembre 2008 (Gran Sala) [TJCE 2008, 269] Caso Jacqueline Förster contra Hoofddirectie van de Informatie Beheer Groep.

132 Sentencias de 21 de junio de 2007 (TJCE 2007, 147), ROM-projecten, C-158/06, apartado 25; de 1 de octubre de 1998 (TJCE 1998, 226), Reino Unido/Comisión, C-209/96, apartado 35; de 20 de mayo de 2003 (TJCE 2003, 149), Consorzio del Prosciutto di Parma y Salumificio S. Rita, C-108/01, apartado 89, y de 21 de febrero de 2006 (TJCE 2006, 383), Halifax y otros, C-255/02, apartado 72.

133 Siendo evidente que la plenitud del Derecho enlaza con la paz social.

134 Constitución Española de 1978. Dicho precepto dispone que “La Constitución garantiza el principio de legalidad, la jerarquía normativa, la publicidad de las normas, la irretroactividad de las disposiciones sancionadoras no favorables o restrictivas de derechos individuales, la seguridad jurídica, la responsabilidad y la interdicción de la arbitrariedad de los poderes públicos".

135 La prohibición de la retroactividad sólo es aplicable a los derechos consolidados, asumidos e integrados en el patrimonio del sujeto, y no a los pendientes, futuros, condicionados, ni a las expectativas. En tal sentir vid SSTC 70/1988, de 19 de abril (RTC 1988, 70) y 108/1986, de 29 de julio (RTC 1986, 108).

136 SSTC 104/2000, de 13 de abril (RTC 2000, 104), Fto Jur 7; y 235/2000, de 5 de octubre (RTC 2000, 235 ), Fto Jur 8.

137 STC 46/1990, de 15 de marzo (RTC 1990, 46), Fto Jur 4.

138 STC 36/1991, de 14 de febrero (RTC 1991, 36), Fto Jur 5.

139 SSTC 234/2001, de 13 diciembre [RTC 2001, 234], 150/1990, de 4 de octubre, F. 8; 142/1993, de 22 de abril [RTC 1993, 142], F. 4; 212/1996, de 19 de diciembre [RTC 1996, 212], F. 15; y 104/2000, de 13 de abril [RTC 2000, 104], F. 7.

140 Si la conducta de los poderes públicos es "sorpresiva y no esperada ni ajustada a las condiciones vigentes" mediante disposiciones transitorias (STS de 24 de mayo de 1988 -Ar. 4203-) es exigible la reparación del perjuicio económico injustificado que pueda producirse (STC 197/1992, de 19 de noviembre, y STC 205/1992, de 26 de noviembre).

141 Y la garantía de cumplimiento del Derecho por sus destinatarios se alcanza con el sometimiento de ciudadanos y poderes públicos a ese ordenamiento jurídico, lo que deriva del principio de legalidad.

142 Evoquemos a S. Isidoro de Sevilla, en atención a la certeza jurídica, al indicar que la ley debe ser clara, no se dé que por su oscuridad induzca a error (Etimologias; Libro 5, n. 21: “... manifesta quoque, ne aliquid per obscuritatem in captionem conteineat”).

143 Es aquí donde el principio de la seguridad jurídica se enlaza especialmente con la jerarquía normativa y la reserva de ley, al objeto de dotar de coherencia, unidad y consistencia al propio ordenamiento jurídico, dotado de un sistema de fuentes, a la vez que prevé técnicas de integración de las normas jurídicas. En este sentido, podemos encontrar algún pronunciamiento del Tribunal Constitucional español que enfa- 
segunda, se logra y concibe con antelación la toma de conciencia de los efectos que despliega ante el proceder de los comportamientos propios o de terceros. Así se puede saber "a qué atenerse", ajustando el destinatario de toda norma su conducta a lo razonable, juiciosa y sensatamente previsible ${ }^{144}$. Por la tercera, se nos instituye la familiaridad, la cotidianeidad y la convicción de esa regla ${ }^{145}$. Es una cierta permanencia, perdurabilidad, sin que se llegue a la petrificación o anquilosamiento del ordenamiento.

Estos axiomas, a su vez, se enlazan con otros que están en íntima relación con el principio de seguridad jurídica, tales como la prohibición de arbitrariedad, la responsabilidad de los poderes públicos, la “ignorantia iuris”, la eficacia del Derecho y la obediencia al mismo.

En palabras del Consejo de Estado, en su Memoria 1992, "la seguridad jurídica garantizada en el art. 9.3 CE significa que todos, tanto los poderes públicos como los ciudadanos sepan a qué atenerse, lo cual supone por un lado un conocimiento cierto de las leyes vigentes y, por otro, una cierta estabilidad de las normas y de las situaciones que en ella se definen. Esas dos circunstancias, certeza y estabilidad, deben coexistir en un estado de Derecho". No obstante, las ideas de progreso o mejoramiento social y de solidaridad constituyen un límite a la inmutabilidad del Derecho que podría albergar el principio de la seguridad jurídica, en tanto no quiebre la paz social'146.

Es decir, que aparte de los ya indicados por el Tribunal Constitucional español, la seguridad jurídica despliega sus efectos en conexión a otros principios y técnicas que permiten promover, en el orden jurídico, la justicia y la igualdad en libertad, tales como: el de la propia técnica legislativa en la producción de las normas (tendiendo a su claridad) ${ }^{147}$, la cosa juzgada, el respeto a los derechos adquiridos, la buena fe o incluso el principio de "confianza legítima".

Precisamente, uno de los principios jurídicos que regulan las relaciones entre el poder público y los ciudadanos en el ámbito de la Unión Europea ${ }^{148}$ y, concretamente, en España, es el principio de la confianza legítima ${ }^{149}$, cuya más importante consecuencia es la de atenuar (e incluso dejar sin eficacia en casos concretos) el rigor del principio de legalidad, en cuya virtud, incluso se establecen límites a las potestades revocatorias de la propia Administración ${ }^{150}$.

tiza en sentido parecido exponiendo que: "Las normas no son elementos aislados e incomunicables, se integran en un conjunto -Ordenamiento jurídico- en cuyo seno de acuerdo con unos principios han de resolverse los problemas" (sentencia 150/1990 [RTC 1990, 150]).

144 Previsibilidad que también conecta con la unidad y continuidad de la jurisprudencia (de las resoluciones judiciales), la cosa juzgada, los derechos adquiridos y la "confianza legítima". Vid también el trabajo de Garrido Gómez, María Isabel, "La predecibilidad de las decisiones judiciales", lus et Praxis, 2009, vol.15, no.1, p.55-72. ISSN 0718-0012.

145 En cierta medida, esta particularidad se articula con la estabilidad, la permanencia y la continuidad del ordenamiento jurídico. Y esa característica enlaza con el principio de irretroactividad de las normas (si bien en el terreno internacional tiene matices importantes) y con el principio de continuidad y de conservación del Ordenamiento jurídico.

146 La STC 27/1981, de 20 de julio, señala (y como ya apuntamos antes) que la seguridad jurídica es "suma de certeza y legalidad, jerarquía y publicidad normativa, irretroactividad de lo no favorable, interdicción de la arbitrariedad...", pero "no ampara la necesidad de preservar indefinidamente el régimen jurídico que se establece en un momento histórico dado en relación con derechos o situaciones determinadas" (STC 227/1988) pues ello conduciría a la petrificación o fosilización del ordenamiento.

147 Vid sobre el particular el trabajo de Rodríguez-Arana Muñoz, Jaime, titulado "Principio de seguridad jurídica y técnica normativa", Repertorio Aranzadi del Tribunal Constitucional num. 4/2007 parte Estudio, quien enuncia a la seguridad jurídica como "Principio esencial en todo Estado de Derecho". Y aboga por una técnica normativa en condiciones de inteligibilidad, es decir, que las normas sean redactadas en un lenguaje entendible por los destinatarios de las mismas.

148 Según reiterada jurisprudencia, el principio de protección de la confianza legítima se considera como parte del ordenamiento jurídico comunitario y debe ser respetado por los Estados miembros cuando aplican las normativas comunitarias (vid, en este sentido, Sentencias de 26 de abril de 1988 [TJCE 1988, 141], Kru cken, 316/86, Rec. p. 2213, apartado 22; de 1 de abril de 1993 [TJCE 1993, 45], Lageder y otros, asuntos acumulados C-31/91 a C-44/91, Rec. p. I-1761, apartado 33; de 3 de diciembre de 1998 [TJCE 1998, 307], Belgocodex, C-381/97, Rec. p. I-8153, apartado 26, y de 8 de junio de 2000 [TJCE 2000, 125], Schloßtraße, C-396/98, Rec. p. I-4279, apartado 44).

149 El principio de confianza legítima fue incorporado al derecho interno español por Ley foral navarra 6/1990, de 2 de julio, de Administración local.

150 En efecto, el Tribunal Supremo en las siguientes sentencias en las que aplica el artículo 112, LPA (hoy art. 106, LRJPA), establece límites a las potestades revocatorias de la Administración: $1^{\circ}$.Sentencia del TS de 7 de junio de 1982, Sala 3. ${ }^{a}$, Ponente: Roldán (RJ 1982, 3616): "Aunque el artículo 109 de la LPA señala que "en cualquier momento" la Administración podrá declarar la nulidad de los actos enumerados en el artículo 47 de la misma (en forma análoga para los dictados en vía de gestión tributaria lo establece el art. 154 de la LGT); pero tanto el artículo 112 de la LPA como el 154 citado se fijan límites a las facultades de revisión de oficio, dado que al anular un acto administrativo declarativo de derechos, o favorable, entran en conflicto dos principios básicos de todo Ordenamiento Jurídico, el de la seguridad jurídica y el de la legalidad, exigiendo el primero que se ponga un límite a las facultades de revisión de oficio y consiguientes impugnaciones de actos o disposiciones administrativas amparadas por la presunción de legitimidad y cuando se llega a ese límite hay que dar eficacia y consagrar la situación existente, principio de seguridad que tiene un valor sustantivo y puede ser alegado y opuesto por las partes litigantes y estimado incluso de oficio puede ser motivo de desestimación de la demanda...”. Y $2^{\circ}$ la Sentencia de 10 de mayo de 1987, Sala 4. ", Ponente: González Navarro (RJ 1987, 2923): “Este principio de equidad puede venir en este caso reforzado por la analogía de las circunstancias que aquí concurren, con las enumeradas en el artículo 112, LPA, lo que legitima la aplicación de éste también por analogía, ya que este precepto tiene en cuenta el tiempo transcurrido, que es lo ocurrido en el supuesto de autos, aunque aquí determine la anulación del acto, como solución, a sensu contrario, de la prevista en dicho artículo 112. Que, incluso antes de estas introducciones legislativas del Cc y de la LPA, ya la jurisprudencia había declarado que hay circunstancias en que la Justicia y el Derecho han de auxiliarse de la equidad -S. de 10 de octubre de 1955-, puesto que la equidad es un principio general de Derecho que puede operar como supletorio del mismo -S. de 21 de octubre de 1957-, principio que se mantiene en diversidad de ocasiones [... ].El Tribunal, por ello, considera que para aproximarse a la justicia del caso hay que recurrir a la equidad. En el bien entendido, de que aplicar una solución de equidad no significa de ningún modo emplear un criterio de benevolencia. Se trata, simplemente, de hacer justicia, o si se quiere, de llegar a la justicia del caso. La equidad es una forma de normatividad no jerarquizada. Y su aplicación es aquí posible porque existe la ley de que habla el artículo 3 del Código civil que permite su aplicación. En 
De tal suerte que si existen unos actos concluyentes, generadores de confianza ("umbral de confianza") del afectado en que la Administración actúa correctamente, en que es lícito su proceder y relación ${ }^{151}$, en que sus expectativas ${ }^{152}$ como interesados son razonables ${ }^{153}$, entra en juego el indicado principio de confianza legítima. $Y$ entre los efectos que despliega dicho principio, destaquemos el de operar como límite al ejercicio de las potestades discrecionales ${ }^{154}$.

Y en íntima relación con la confianza legítima brota el principio de la buena fe ${ }^{155}$, que se recogía ya en nuestro Código Civil como límite al ejercicio de los derechos, al que se le dota de cierto "valor constitucional”156. Asimismo habría que enunciar la congruencia entre lo pedido por el ciudadano y lo resuelto por la Administración, pues ello se ha fundar en la protección de la confianza.

Por otra parte, la innovación y adaptación de las normas es inevitable e ineludible, en aras del progreso o mejoramiento social y de la solidaridad, si bien, deberán respetar, en la medida de lo posible, los principios anteriormente citados, y más concretamente los principios de seguridad jurídica y de confianza legítima, al objeto de no quebrantar la paz social, debiendo existir una justificación o motivación adecuada, idónea y suficiente que obligue a soportar esa cierta "fluctuación" jurídica. Los cambios normativos que se produzcan deben intentar, siempre que sea posible, hacer compatibles los intereses públicos y privados en juego mediante la previsibilidad y la motivación. "Hay en todo caso una regla general, aplicable tanto al administrador como al juez: la necesidad de fundamentar toda decisión y de fundamentarla, precisamente, en Derecho y no en el deseo, en la voluntad, en el capricho, en las preferencias o en los gustos de quien la adopta. En un Estado de Derecho sólo lo fundamentado y justificado en Derecho es razonable y sólo lo razonable es jurídicamente admisible" "157. Y la motivación es causa necesaria pero no suficiente, es decir, que no vale cualquier motivación.

Los principios de legalidad y de seguridad jurídica también son asumidos por el Derecho Internacional, ostentando una doble perspectiva: como principios generales del Derecho que informan al resto del ordenamiento jurídico internacional y como valores a tener en cuenta porque condicionan el comportamiento de los sujetos de la Sociedad Internacional, tanto el de los Estados como el de las Organizaciones Internacionales.

Conversar sobre seguridad, es brindar un clima de confianza, de certidumbre, de tranquilidad en las relaciones sociales que se dan a nivel internacional y que permiten una verdadera actuación libre de los sujetos que participan en la misma. Y cuando se trata de Seguridad Jurídica se refiere al origen, ejercicio y limites del Poder, esta garantía central es el imperio de la Ley donde se expresa de forma indiscutible en la relación del Derecho y el poder, en cuya virtud el Derecho se convierte en regulador y racionalizador del uso de la fuerza y asegura, tranquiliza, da certeza y permite a todos saber a qué atenerse. La seguridad jurídica en relación con el Derecho supone la existencia en el propio ordenamiento jurídico de los mecanismos, técnicas formuladas como principio de organización o interpretación o como derechos de los sujetos a los que el ordenamiento se dirige y en este ámbito encontramos como consecuencia y exigencia de la propia seguridad jurídica. Por consiguiente la seguridad jurídica es requisito de la Libertad y Justicia.

El principio de legalidad en su vertiente internacional, conlleva, por un lado, un ordenamiento jurídico completo, cabal y claro, por otro, la igualdad ante la ley de todos los sujetos de dicho ordenamiento, por otro, la efectiva

efecto, el artículo 112, LPA, dice que "las facultades de anulación y revocación no podrán ser ejercitadas cuando [...] su ejercicio resultase contrario a la equidad". Y es lo que aquí ocurre. Porque la Administración, que durante años ha venido tolerando la acampada de Matalascañas (incluso los abusos, que se dice se han cometido, de realquilar la caseta), que reguló esa acampada estableciendo alineaciones, distancias entre unas casetas y otras, servicios higiénicos municipales para cubrir las deficiencias de fosas sépticas de algunas de esas casetas, que percibió saneadas tasas por las autorizaciones, etcétera, es discutible que pudiera revocar aquella autorización. La equidad lo impedía según el artículo 112 de la Ley de Procedimiento Administrativo".

151 STS. de 22 de diciembre de 1994 (RJCA 1994, 621).

152 Las expectativas sólo serán protegibles si se sustentan en bases objetivas, de modo que un observador externo pueda reconocerlas y calibrar su dimensión objetivable. Esto es lo que la STJCE de 17 de diciembre de 1992 (Holtbecker vs. Comisión) ha denominado "esperanzas fundadas no contrarias al Derecho Comunitario".

153 STS. de 28 de febrero de 1989, Sala 3a , Ponente: Martínez Sanjuán (RJ 1989, 1458).

154 En tal sentir vid, a mero título de ejemplo, SSTS de 7 de octubre de 1991 [Sala 3 $3^{\text {a }}$ Sección $3^{\text {a }}$, Ponente: Martínez Sanjuán (RJ 1991 , 7520)], y de 26 de enero de 1990 (Sala 3ª Sección 3ª, Ponente: Martínez Sanjuán (RJ 1990, 598)].

155 Ambos hoy normativizados en el derecho español en el artículo 3 de la ley 30/1992, de 26 de noviembre, de Régimen Jurídico de las Administraciones Públicas y del Procedimiento Administrativo Común (“Igualmente, (las Administraciones Públicas) deberán respetar en su actuación los principios de buena fe y de confianza legítima"). El dictamen del Consejo de Estado de 22 de enero de 1998 señalaba que "el principio de protección de la confianza legítima, cuyo significado no es ajeno al principio de buena fe,..., es un principio de carácter general vinculado a los principios de seguridad jurídica, buena fe, interdicción de la arbitrariedad y otros con los que suele combinarse y, por supuesto, no requiere la preexistencia de derechos subjetivos, que tienen otras vías de protección".

156 Concretamente en su artículo 7, que también prohíbe el abuso del derecho o el ejercicio antisocial del mismo. Dicho art. 7, como integrante del Título Preliminar del Código Civil, tiene según la STC 37/1987, de 26 de marzo, un "valor constitucional” puesto que sus normas se refieren a la aplicación y eficacia de todo el ordenamiento y no sólo de la legislación civil, ubicándose en el Código Civil sólo por tradición histórica.

157 Tomás Ramón Fernández, en su obra “De la Arbitrariedad de la Administración”, publicado en Civitas, $1994 ;$ pág. 223. 
aplicación del Derecho y, por último, la ausencia de poder arbitrario, desechando toda acción despótica, caprichosa o irresponsable frente a la regulación legal.

Así en la Convención de Viena sobre el derecho de los tratados entre Estados y Organizaciones internacionales o entre Organizaciones internacionales de 21 de marzo de $1986^{158}$ se reconoce que todo Estado tiene capacidad para celebrar tratados, y que todo tratado 159 "en vigor obliga a las partes y debe ser cumplido por ellas de buena

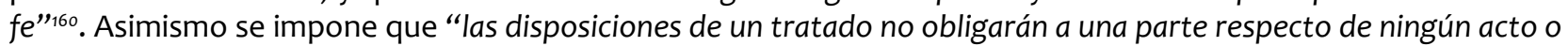
hecho que haya tenido lugar con anterioridad a la fecha de entrada en vigor del tratado para esa parte ni de ninguna situación que en esa fecha haya dejado de existir, salvo que una intención diferente se desprenda del tratado o conste de otro modo" "161, debiendo "interpretarse de buena fe conforme al sentido corriente que haya de atribuirse a los términos del tratado en el contexto de éstos y teniendo en cuenta su objeto y fin"162. Sobre esa buena fe hemos de evocar también la Resolución 2625 (XXV) de la Asamblea General de Naciones Unidas, de 24 de octubre de 1970, que contiene la Declaración sobre los principios de Derecho Internacional referentes a las relaciones de amistad y a la cooperación entre los Estados de conformidad con la Carta de las Naciones Unidas ${ }^{163}$.

En suma, tanto a nivel internacional, como a nivel europeo, como a nivel nacional se ha de atender a la buena fe, al principio de legalidad, al principio de seguridad jurídica y al de confianza legítima.

\section{LA AMENAZA DE LOS BIENES DECLARADOS PATRIMONIO DE LA HUMANIDAD: LOS INFORMES DE ICOMOS DE 2008 Y 2011}

\section{A) Informe año 2008}

En relación con la justificación del informe, éste (se dice en el mismo) se inspira principalmente en el párrafo 173 de las Directrices Prácticas para la Aplicación de la Convención del Patrimonio Mundial (última edición de enero de 2008), en adelante citadas simplemente como Directrices, y que tiene como objetivo identificar "cualquier amenaza, daño o pérdida del Valor Universal Excepcional, la integridad y/o la autenticidad que justificaron la inscripción del bien en la Lista del Patrimonio Mundial", en este caso la triple inscripción unitaria de la Catedral-Giralda, el Alcázar y el Archivo de Indias de Sevilla. Y si bien expone que no va a entrar a valorar el impacto paisajístico, lo cierto es que en lo único en que se centra ${ }^{164}$ es en dicho pretendido impacto sin ninguna prueba que lo avale, y todo ello expuesto por persona que no es experta ni ostenta título profesional cualificado ni acreditado en impacto visual o paisajístico, aparte de ser un extraño examen excesivamente parcial y subjetivo, que denota una manifiesta intencionalidad. Pues así y todo se le presta atención al mismo y se propone una Zona de amortiguación que después fue aceptada.

\section{B) Antecedentes al Informe año 2011}

Durante la 33 Sesión del Comité de Patrimonio Mundial'165, se acuerda crear una Comisión de "Expertos" para valorar el impacto de la "Torre Pelli" sobre los monumentos declarados Patrimonio Mundial por la UNESCO en 1987, Catedral, Alcázar y Archivo de Indias. No obstante, y previo a ello el Gobierno de España elevó al Comité de Patrimonio Mundial los informes realizados por especialistas e instituciones públicas, donde se analiza la relación visual entre la "Torre Pelli" y su percepción desde el interior de los monumentos y desde su entorno inmediato,

158 Recordemos que la proliferación de acuerdos internacionales en los que participaban Organizaciones Internacionales llevó a la Conferencia de Viena que adoptó el Convenio sobre el Derecho de los tratados del 23 de mayo de 1969 a recomendar a la Asamblea General de la N.U. la preparación de un nuevo convenio, esta vez referido a los tratados celebrados entre Estados y Organizaciones internacionales entre Organizaciones internacionales. Respondiendo con la resolución 2501 (XXIV) de 12 de noviembre de 1969, encargando a la Comisión de Derecho Internacional el estudio de este tema. Tras varios años se formularon una serie de artículos que fueron objeto de discusión en la Conferencia de Viena desarrollada el 18 de febrero al 20 de marzo de 1986, de donde salió el texto del Convenio sobre el Derecho de los tratados entre Estados y Organizaciones internacionales o entre Organizaciones internacionales, abierto a firma el 21 de marzo de 1986.

159 Recordemos que se entiende por "tratado" (ex art. 2 de la Convención de 1986) "un acuerdo internacional regido por el derecho internacional y celebrado por escrito: i) entre uno o varios Estados y una o varias organizaciones internacionales; o ii) entre organizaciones internacionales; ya conste ese acuerdo en un instrumento único o en dos o más instrumentos conexos y cualquiera que sea su denominación particular".

160 Ex art. 26 de la Convención de 1986.

161 Irretroactividad de los tratados ex art. 28 de la Convención de 1986.

162 Ex art. 31.1 de la Convención de 1986.

163 En cuya virtud "El principio de que los Estados cumplirán de buena fe las obligaciones contraídas por ellos de conformidad con la Carta. Todo Estado tiene el deber de cumplir de buena fe las obligaciones que ha contraído en virtud de la Carta de las Naciones Unidas. Todo Estado tiene el deber de cumplir de buena fe las obligaciones contraídas en virtud de los principios y normas de Derecho Internacional generalmente reconocidos. Todo Estado tiene el deber de cumplir de buena fe las obligaciones contraídas en virtud de acuerdos internacionales válidos con arreglo a los principios y normas de Derecho Internacional generalmente reconocidos".

164 Enfatiza que "este informe no entra a valorar si la obra se corresponde con un buen o un mal proyecto de arquitectura, sino que tratará de exponer si un mal planteamiento urbanístico puede alterar los valores de algunos de los bienes sevillanos inscritos en la Lista del Patrimonio Mundial". Y añade "Tampoco es un análisis del impacto paisajístico de la obra, [... ], sino una interpretación de los aspectos básicos del proyecto a la luz de los principales textos normativos y orientativos que debieran haberse utilizado" (pág. 3 del Informe).

165 Celebrada en Sevilla entre los días 23 y 29 de junio de 2009 se adopta la Decisión 33 COM 7B.123 (en base al informe ya citado). 
dejándose prueba de la inexistencia de impacto visual por el viandante. También se ha de citar que en la Sesión de 2009, celebrada en Sevilla, se insta para que se defina una Zona de Amortiguamiento que fue presentada bajo la denominación de "Documento de Delimitación de la Zona de Amortiguamiento del ámbito Patrimonio Mundial de Sevilla". Y será la 34

Sesión del Comité de Patrimonio Mundial de 2010 la que acuerda el establecimiento de dicha Zona de Amortiguamiento $^{166}$.

Las características singulares de los tres monumentos incluidos en la Declaración de 1987 y, particularmente, las características de la Giralda como hito visual, fueron objeto de un análisis perceptivo para establecer la Zona de Amortiguamiento motivada por criterios visuales y paisajísticos con relación a la imagen histórica a la que se asocian dichos monumentos. Dicho análisis diferenciaba dos escalas de percepción del paisaje urbano de Sevilla: su paisaje urbano histórico, vinculado al casco antiguo de la ciudad y a su indisoluble relación con la dársena del Guadalquivir como río "histórico"; y el paisaje de la ciudad de la periferia y de su área metropolitana.

A ello han de colegirse las características topográficas de Sevilla (ciudad sensiblemente horizontal sin apenas accidentes topográficos), dado que su lugar de emplazamiento se sitúa históricamente en el cauce de avenidas del Guadalquivir, y hacen que la percepción visual de sus hitos verticales sea muy limitada. Ello supone que la visión del conjunto monumental sólo se perciba desde su entorno inmediato, junto a cada uno de los monumentos interrelacionados visualmente entre sí por su proximidad, y que sólo la torre de la Giralda se eleva sobre la horizontalidad del paisaje urbano sevillano, adquiriendo protagonismo en algunas vistas lejanas, pero ya descontextualizado del propio conjunto monumental, incluso del Casco Histórico de Sevilla ${ }^{167}$. Y así se propuso una delimitación de la Zona de Amortiguamiento que recogía los componentes del paisaje histórico urbano que se configuraron en relación a los acontecimientos que dieron a Sevilla relevancia universal ${ }^{168}$.

De esta Zona de Amortiguamiento, reflejar que se puede trazar sobradamente, dentro de su perímetro, una circunferencia de 500 metros de radio y con centro en la Giralda.

No obstante, no debe olvidarse que al contrario que sucede en otras ciudades (como por ejemplo con Córdoba, Ávila, Cáceres, Salamanca, Santiago de Compostela, Segovia o Toledo) ${ }^{169}$, en Sevilla no se ha inscrito como Patrimonio de la Humanidad su Casco Histórico, sino exclusivamente el conjunto monumental Catedral-Archivo de Indias-Reales Alcázares.

\section{C) Informe año 2011}

Pues bien, al no estar previamente delimitada una zona de amortiguación (al menos resultaba innecesaria para el año 1987, fecha en que se inscribió), con posterioridad fue aprobada el que delimitara una en el año 2010 lo que fue aceptado por el Comité. No obstante, en el informe del Noviembre de 2011 se estima, sin más, que es insuficiente ${ }^{170}$.

166 Sesión celebrada en Brasilia entre el 25 de julio y el 3 de agosto de 2010, adoptó la Decisión 34COM 7B.100 sobre la defensa y conservación de los bienes declarados, acordó el establecimiento de la Zona de Amortiguamiento del propio ámbito donde se asientan los bienes declarados en 1987.

167 Asimismo, ha de tenerse presente que la altura de las pilas del puente del V Centenario (de 105 metros cada una), actúan de algún modo como referencias visuales en el paisaje metropolitano sevillano. Y, del mismo modo, la altura de la pila del viaducto de San Lázaro está situada a 142 metros. Hitos visuales que acotan y perfilan el paisaje.

168 En el interior de esta Zona de Amortiguamiento destacan varios edificios (aparte de los 3 monumentos de la declaración de Patrimonio de la Humanidad de la UNESCO), a saber: a) La Casa de la Moneda, (BIC Monumento. BOE 14/04/1970), b) Convento de los Remedios, (BIC Monumento. Gaceta de Madrid 06/11/1931), C) Convento de Madre de Dios, (BIC Monumento. BOE 28/07/1971), d) Hospital de la Caridad (BIC Monumento. BOJA 07/11/1992), e) Colegio Náutico de San Telmo (sede actual de la Presidencia de la Junta de Andalucía; BIC Monumento. BOE 29/04/1968), f) Fábrica de Tabacos (BIC Monumento. BOE 01/06/1959), g) Las Atarazanas alfonsíes del siglo XIII (BIC Monumento. BOJA 07/11/1992), y, podríamos citar también el edificio del propio Ayuntamiento de Sevilla.

169 El 17 de septiembre de 1.993 se constituyó en Ávila el Grupo de Ciudades Patrimonio de la Humanidad de España, como una Asociación integrada por aquellos municipios españoles con conjuntos históricos, que en aquel momento se encontraban inscritos en la lista del Patrimonio Mundial de la UNESCO: Ávila, Cáceres, Salamanca, Santiago de Compostela, Segovia y Toledo decidieron aunar esfuerzos para la actuación conjunta en defensa y promoción de su patrimonio histórico y cultural. Posteriormente, se unirían a la Asociación las ciudades de Córdoba, Cuenca, Alcalá de Henares, Ibiza - Eivissa y San Cristóbal de La Laguna. Desde el primer momento se ha visto las posibilidades que se obtenían ofreciendo a los potenciales turistas, no una competencia, sino un complemento a la oferta del turismo de Sol y Playa, proponiendo esta otra alternativa del Turismo Cultural y de Calidad histórica y artística de nuestras ciudades.

170 En dicho informe podemos leer lo siguiente: “Una propuesta para una zona de amortiguación fue aprobada durante la $34^{a}$ reunión del Comité WH en julio de 2010. La zona de amortiguación, dentro de un área de 205 hectáreas, está vinculada a los tres componentes de la propiedad a través de históricos, patrimonio y motivos visuales. Que también incluye partes del río, que ha marcado el desarrollo de la ciudad y partes de las orillas opuestas, pero no se extiende a cubrir el sitio de la Torre Cajasol (mapa). El Centro de Patrimonio Mundial ICOMOS consideran que i) la zona, que el Estado parte ha identificado como una zona de amortiguación, es sin duda importante y debe ser protegida; ii) esta área ofrece la configuración a la ciudad y luego la altura de la Torre va más allá de la configuración inmediata y podrían tener un impacto negativo sobre la integridad visual del conjunto". De hecho el Comité WH en sus consideraciones afirma que la "... de hecho la protección de esta área en el contexto más amplio en términos de potenciales desarrollos de edificios altos que deban ser considerado a través de evaluaciones de impacto visual para su posible impacto 
Al menos, en la doctrina y jurisprudencia española tenemos clara y nítida la diferencia entre la discrecionalidad y la más absoluta arbitrariedad.

\section{D) Algunas reflexiones sobre esos Informes}

$\left.1^{\circ}\right)$ Comencemos por analizar qué es, o qué debe entenderse por "peligros graves y precisos", que podrán ser reales o potenciales. Al menos en castellano, por Peligro grave (real o potencial), entendemos una amenaza importante, trascendental, capital, seria. Sería algo así como que se vaya a caer, a demoler o que lo vayan a tirar, o que se realicen obras en el entorno y puedan amenazar a la estabilidad de los monumentos.

Pues bien, descartemos lo que irrefutablemente no entraría en los supuestos previstos por esas cambiantes y versátiles Directrices ${ }^{171}$. Esos cambios que se van sucediendo en esas Directrices generan la incertidumbre proscrita y podría ir incluso contra la buena fe, sobre todo si se aplica con carácter retroactivo. No obstante, el único "peligro" que podría citarse (por decir algo) es el de Grave alteración del espacio urbano, y parece que es aquí donde debemos centrarnos.

Ante todo reiterar que en 1987 fue aceptada la propuesta de la Catedral, el Alcázar y la Lonja (convertido en 1784 el Archivo General de Indias) y estas propiedades culturales fueron incluidas en la Lista del patrimonio mundial, en la que NO SE DEFINIÓ NINGUNA ZONA DE AMORTIGUACIÓN. Y se justificaba exponiendo que no se definía "zona de amortiguamiento" ("Buffer zone") por resultar innecesaria puesto que El Alcázar es un recinto amurallado y protegido ${ }^{172}$. Pues de todos los informes realizados (no tenidos en consideración por ICOMOS) se concluye que no existe afección visual ni “contaminación visual o perceptiva”"173.

$\left.2^{\circ}\right)$ Pero ¿qué ha de preservarse? Es evidente que el Valor Universal Excepcional Histórico-arquitectónico del conjunto monumental de Sevilla ("encarnan perfectamente la historia de España y su "Edad de oro"..."). Repárese que en la propia declaración que sirve de límite a la inscripción no llega a definirse el entorno en el que está localizado. Y según los textos a los que tenemos que acudir es al momento de la Inscripción al que tenemos que atender, pues es cuando se adopta la "Declaración de Valor Universal Excepcional" y ésta sirve de referencia para la protección y la gestión eficaz del bien en el futuro, según hemos visto. Igualmente habíamos visto que la protección ha de abarcar unos límites claramente definidos, y de ahí que se exija que "en la propuesta de inscripción tendrán que adjuntar textos que contengan una clara explicación sobre cómo se implementa la protección jurídica del bien en cuestión". Es más, en el caso de los bienes propuestos según los criterios (i) (vi) [cual acontece con el conjunto monumental de Sevilla] "Ios límites se establecerán de manera que incluyan todas las áreas y los atributos que sean expresión tangible directa del Valor Universal Excepcional del bien, además de las áreas que, considerando posibilidades futuras de investigación, podrían contribuir a su comprensión y a mejorar ésta". Y decíamos que los límites del bien propuesto podrán coincidir con una o varias zonas protegidas existentes o propuestas, como "un barrio histórico protegido".

La denominada "Zona de amortiguamiento", a su vez, se definía como un "área alrededor del bien cuyo uso y desarrollo están restringidos jurídica y/o consuetudinariamente a fin de reforzar su protección" (entorno inmediato). Así se enuncia que "cuando la conservación adecuada del bien lo requiera, deberá establecerse alrededor del bien una zona amortiguamiento". Dicha "Zona de amortiguamiento" (o "zona tampón de amortiguamiento") tenía que estar incluida en la propia Propuesta de inscripción, cosa que en Sevilla se obvió por innecesaria. Y ahora pasamos de

sobre el valor Universal excepcional".

171 Grave alteración de los materiales, NO pues está en muy buen estado de conservación habiéndose llevado a cabo obras de conservación e incluso de adecentamiento del entorno (con peatonalizaciones).

Grave alteración de las estructuras, NO pues está en muy buen estado de conservación habiéndose llevado a cabo obras de conservación como hemos visto.

Grave alteración de la ornamentación, NO pues está en muy buen estado de conservación habiéndose llevado a cabo obras de conservación.

Grave alteración de la coherencia arquitectónica, NO pues incluso se han peatonalizado las zonas adyacentes. Grave alteración de la coherencia urbanística, NO en donde se mantiene el régimen de protección (los 3 son BIC y su entorno también es BIC -conjunto histórico de Sevilla-).

Grave alteración del significado cultural, NO, pues el mismo permanece inalterado.

Pérdida significativa de la autenticidad histórica, NO.

Grave alteración de las características esenciales, NO.

172 No obstante, y referente al entorno urbano, en el propio Informe de 2011 leemos lo siguiente: "Asimismo se garantiza la conservación de edificios individuales también asociados con el comercio español en las Américas en el corazón histórico de la ciudad que sirve como escenario urbano de los tres monumentos y las características generales de ese entorno urbano". Y añade el informe de 2011 "Dada la enorme extensión de este Conjunto Histórico..." ". En efecto, se trata de un Conjunto Histórico de $7.835 .000 \mathrm{~m} 2$ con un total de 6.875 fincas catalogadas.

173 Recordemos que nuestra legislación autonómica entiende por "contaminación visual o perceptiva" "aquella intervención, uso o acción en el bien o su entorno de protección que degrade los valores de un bien inmueble integrante del Patrimonio Histórico y toda interferencia que impida o distorsione su contemplación” (art. 19.1 de la Ley 14/2007, de 26 de noviembre, de Patrimonio Histórico de Andalucía). 
un lado del péndulo al opuesto, es decir, de resultar innecesaria la zona de amortiguamiento a proponerse una en la que sobradamente se puede trazar un círculo con un radio de 500 metros, y aún así se dice que es insuficiente, lo que resulta hasta demencial.

$3^{\circ}$ ) Se parte de una concepción que no tiene el más mínimo apoyo, ni fundamentación jurídica en los textos internacionales, por lo que al ser extraño a la seguridad jurídica deberían haber sido repudiados. A saber: toda la problemática la hacen gravitar acerca de la visión de la Giralda desde diversos puntos no ya de la propia Ciudad de Sevilla, sino de su entorno "metropolitano". Pero sólo la Giralda, pues el resto de los monumentos no son perceptibles desde esos lugares alejados, debido a esa topografía horizontal de la ciudad de Sevilla salvo en el indicado entorno inmediato. Y habiéndose hecho múltiples estudios sobre el impacto visual, y habiendo todos concluidos en que es inexistente dicho impacto, no obstante, ICOMOS sigue insistiendo bajo la abierta, que no velada, “amenaza” de incluirlo en la Lista en Peligro y llegarlo a quitar de la Lista de Patrimonio Mundial.

$4^{\circ}$ ) Se han realizado varios estudios de impacto visual de la Torre Pelli en Sevilla, ejecutados por cada una de las Administraciones territoriales (Local, Autonómica y Estatal) y todas concluyen en que, dada la topografía de la ciudad de Sevilla (prácticamente llana), no existe ningún impacto visual, por cuanto un viandante alrededor de los tres monumentos que componen la declaración de Patrimonio de la Humanidad no puede ver nada de dicha Torre. De donde se infiere, irrefutable e inexorablemente, que no existe ningún tipo de interferencia visual, resultando el entorno, las perspectivas y el paisaje urbano histórico perfectamente salvaguardados, protegidos y permaneciendo inalterables, y en nada interfiere la construcción y finalización de la Torre Pelli, por lo que no existe, ni puede existir contaminación visual o perceptiva. No obstante, sin prueba contradictoria, se prosiguió sosteniendo que existía tal "amenaza", entendemos que contra el "entorno urbano".

$5^{\circ}$ ) El límite para la protección futura de todo monumento, como expusimos más arriba, era el que se contenía en su inscripción. Pues bien, en el caso del conjunto monumental de Sevilla en su inscripción se disponía que NO hacía falta Zona de amortiguación. Sin señalamiento, ni necesidad de esta "zona tampón" de protección se insiste desde ICOMOS en la necesidad de la misma, quebrantando el elemental principio de seguridad jurídica y pretendiendo, con su proceder, violentar esa "paz social” a que más arriba hacíamos alusión, suscitando entre la propia población partidarios y detractores del proyecto de la Torre, pero lo más importante es que lo han provocado amparándose en excluir la declaración de Patrimonio de la Humanidad de ese conjunto monumental "por capricho" de la Lista del Patrimonio Mundial. No obstante, la Administración local se plegó a las exigencias de delimitar una Zona de Amortiguamiento que es defendida por el Estado Español y es la que más arriba hemos expuesto.

Visto que se puede conseguir algo quebrantando el status de seguridad jurídica, vuelven a insistir en ampliar la zona de amortiguación al objeto de que la Torre Pelli sea demolida. ¿Van a pagar ellos los posibles costes de tal proceder? Pues no.

\section{E) La habitualidad de ICOMOS de pronunciamientos en contra de edificios en altura como amenaza grave contra el entorno: Londres}

Esto no es nuevo desde ICOMOS, pues allí en donde se construye en altura, realiza su informe de posible contaminación visual (cosa descartada completamente en el supuesto de Sevilla). En efecto, podemos tomar como ejemplo la propia inscripción de la Torre de Londres ${ }^{174}$, en donde ya el Comité expresó su pesar por la construcción del Tower Hotel, manifestando que hubiera sido mejor evitarlo, tomándose nota de las seguridades de las autoridades del Reino Unido en cuanto a la protección que desde entonces y en adelante se concederá al entorno de la Torre de Londres. El Comité sugirió además que la inscripción en la Lista del Patrimonio Mundial se extendiera al Puente de la Torre, que constituye un todo coherente con la Torre de Londres.

Luego, en la decisión 35COM 7B.114 se llega a sostener incluso que los avances alrededor de la Torre (y referido al entorno) "en los últimos cinco años han impactado negativamente a su integridad visual" y piden al Estado o Parte "a que se abstengan de aprobar nuevos proyectos de construcción en las cercanías de la propiedad sin evaluar su impacto potencial sobre el Valor Universal Excepcional del bien".

174 Decision -12COM XIV.A- Inscription: The Tower of London (United Kingdom). Somination: The Tower of London. Location: London. State Party: United Kingdom. Date: December 28, 1987. C(ii)(iv). 488. La Torre de Londres fue declarada en 1988 Patrimonio de la Humanidad por la Unesco, por tratarse de una fortaleza del medievo normando excepcionalmente bien conservada y por su significación como centro de poder ininterrumpido durante siglos y siglos de historia británica y europea. (Criterios ii, iv). 
Pues bien, no hay ya uno, sino hasta cuatro edificios ${ }^{175}$ en altura desde que se hiciera esa declaración. Y desde entonces se viene haciendo (en los informes de conservación) el mismo tipo de "amenaza" ${ }^{176}$ que realizan con Sevilla. Por el contrario, todos seguimos apreciando la belleza de la Torre de Londres y del Puente, así como su estado de conservación, perdurando dicho monumento para generaciones venideras y en absoluto existe peligro grave.

Si eso lo sostenemos de Londres, con mayor énfasis lo tenemos que declarar con el supuesto de Sevilla, pues, insistimos, desde el entorno inmediato de los monumentos no se puede ver, ni se ve la Torre Pelli, no existiendo afección visual de ningún tipo. Uno de los principios de la UNESCO es el fomento del respeto mutuo y eso mismo es lo que justo quebrantan los informes de ICOMOS.

\section{CONCLUSIONES}

En España, están inscritos en la lista de Patrimonio Mundial 40 bienes $^{177}$, lo que implica ser uno de los países más representados en dicha Lista, consecuencia directa de su ingente esfuerzo por la arraigada protección de su vastísimo patrimonio cultural. Asimismo hemos visto que las propias "normas de directa aplicación" dan suficiente cobertura jurídica al hecho de armonizar las nuevas construcciones con las protegidas por sus valores históricos o artísticos, así como a tener que cuidarse las perspectivas que éstos ofrecen, a la prohibición de limitación del propio campo visual y al esmero por el paisaje en el que están localizados, lo que puede suponer incluso un adelanto a conceptos que hoy se están discutiendo como el del “paisaje urbano histórico" ${ }^{778}$.

Y recordemos que cada uno de los Estados Partes en esa Convención reconoce que tiene la obligación de identificar, proteger, conservar, rehabilitar y transmitir a las generaciones futuras el patrimonio cultural y natural ${ }^{179}$.

También precisar que estamos ante un "conjunto" (monumental), dentro del patrimonio cultural y en los términos previstos por el artículo $1^{\circ}$ de la Convención ${ }^{180}$, que es al que le se otorga el distintivo y la declaración de Patrimonio de la Humanidad por su Valor Universal Excepcional.

Vamos a enunciar, de forma muy sintética, y a modo de conclusiones, lo hasta ahora visto.

$1^{\circ}$ ) Ante todo se ha de partir de los límites de la Inscripción, y observaremos que en ningún lugar de la inscripción se dice que los 3 elementos se tengan que ver desde cualquier parte del entorno de la Ciudad de Sevilla, pues tampoco se podría hacer, sino tan sólo la Giralda.

$2^{\circ}$ ) Auxilio: Nadie ha pedido ayuda. ICOMOS la emprende contra Sevilla en su Informe de 2008 a raíz de la construcción de la Torre Pelli.

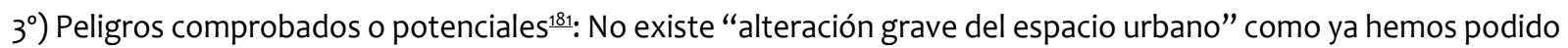
comprobar. Tampoco existe "alteración grave de la coherencia arquitectónica o urbanística”. Del mismo modo, ninguna alegación se hizo al PGOU de Sevilla, ni al PERI del “ARIDT-10 Puerto Triana”, por ICOMOS en su tramitación.

175 a) The Heron Tower (230 m de altura) a $920 \mathrm{~m}$. de la Torre de Londres. b) Tower 42 (183 m de altura) a $916 \mathrm{~m}$. de la Torre de Londres. c) The Gherking (180 m de altura) a $736 \mathrm{~m}$. de la Torre de Londres, se completó en 2004. d) La Torre Shard (310 m de altura) a 815 m. de la Torre de Londres (aún sin terminar su construcción) y adyacente a la estación London Bridge.

176 "Preparar un informe detallado el 15 de diciembre de 2006 para su examen por el Comité del Patrimonio Mundial teniendo en cuenta los párrafos 178 a 186 Directrices Operacionales (la Lista del Patrimonio Mundial en Peligro) y 192-198 (Procedimiento para la exclusión eventual de bienes de la Lista del Patrimonio Mundial), en particular estudiando la posibilidad de inclusión de la propiedad en la Lista del Patrimonio Mundial en Peligro, incluyendo los puntos de referencia y los plazos para la acción correctiva, y presentar el informe al Centro del Patrimonio Mundial en forma electrónica...".

177 Centro histórico de Córdoba (1984,1994), Alhambra, Generalife y Albayzin, Granada (1984,1994), Catedral de Burgos (1984), Monasterio y sitio del Escorial, Madrid (1984), Obras de Antoni Gaudi (1984,2005), Cuevas de Altamira y Arte Paleolítico del norte de España (1985,2008), Centro histórico de Segovia y su acueducto (1985), Monumentos de Oviedo y del Reino de Asturias (1985,1998), Ciudad vieja de Santiago de Compostela (1985), Centro histórico de Avila y sus iglesias extra-muros (1985,2007), Arquitectura Mudéjar de Aragón (1986,2001), Centro histórico de Toledo (1986), Parque Nacional de Garajonay (1986), Centro histórico de Cáceres (1986), Catedral, Alcázar y Archivo de Indias de Sevilla (1987), Ciudad Vieja de Salamanca (1988), Monasterio de Poblet (1991), Conjunto arqueológico de Mérida (1993), Real Monasterio de Santa María de Guadalupe (1993), Camino de Santiago de Compostela (1993), Parque Nacional de Doñana (1994,2001), Ciudad Histórica Fortificada de Cuenca (1996), La Lonja de la Seda de Valencia (1996), Las Medulas (1997), El Palau de la Música Catalana y el Hospital de Sant Pau, Barcelona (1997), Monasterios de San Millán Yuso y Suso (1997), Pirineos Monte Perdido (1997,1999), Arte rupestre de la Cuenca Mediterránea en la Península Ibérica (1998), Universidad y Recinto histórico de Alcalá de Henares (1998), Biodiversidad y cultura de Ibiza (1999), San Cristóbal de la Laguna (1999), Conjunto arqueológico de Tarraco (2000), Iglesias románicas catalanas del Vall de Boí (2000), La Muralla romana de Lugo (2000), Sitio arqueológico de la Sierra de Atapuerca, en Atapuerca e Ibeas de Juarros, Burgos (2000), El Palmeral de Elche (2000), Paisaje cultural de Aranjuez (2001), Dualidad urbana y unidad cultural de Úbeda y Baeza (2003), Puente Colgante de Vizcaya (2006), Parque Nacional del Teide (2007), Torre de Hércules (2009), Sitios de arte rupestre prehistórico del Valle del Côa (Portugal) y Siega Verde (España) (2010), Paisaje Cultural de la Serra de Tramuntana, Mallorca (2011).

178 Ya hemos enunciado algunas normas que se refieren al paisaje, dentro del ordenamiento jurídico español, sin haber sido exhaustivos. Al igual que haber demostrado ser uno de los países en que pronto comenzó la concienciación por la protección del paisaje urbano histórico (o patrimonio cultural y su entorno).

179 Ex art. 4 de la Convención Internacional sobre la protección del patrimonio mundial, cultural y natural de 1972.

180 Convención Internacional sobre la protección del patrimonio mundial, cultural y natural de 1972.

181 Punto 179 de las “Directrices Prácticas para la correcta aplicación de la Convención de Patrimonio Mundial” (Nov. 2011). 
$4^{\circ}$ )_Límites de la inscripción: No existe alteración alguna de los límites inscritos. Existe en los informes de ICOMOS una palpable, notoria y evidente extralimitación de los límites definidos en la inscripción. Los autores de los Informes de ICOMOS no tienen presente ninguno de los límites de los bienes inscritos (sólo los enuncian).

$5^{\circ}$ ) Zona de Amortiguación: En el año 1987 (año de la inscripción) No existe Zona de Amortiguación ("Buffer zone”) en la inscripción. Luego se le dota de ella (propuesta aprobada en la $34^{\text {a }}$ reunión del Comité WH en julio de 2010) -en la que recordemos se puede trazar una circunferencia con un radio de 500 metros-, y sin aceptar esa Zona, ahora se pretende que sea kilométrica.

Además, la zona de amortiguación es la única zona de protección de bienes del patrimonio de la humanidad exigida en los textos oficiales del patrimonio de la humanidad, no existiendo una pretendida "zona de transición".

No se pretende (como zona de amortiguamiento) "un barrio histórico protegido", desnaturalizando, incluso, lo que preceptúan sus propias directrices que lo entiende como "entorno inmediato". Y, por supuesto que debería ser "cuando la conservación adecuada del bien lo requiera" 182 , cosa que es más que discutible en el supuesto de Sevilla.

$6^{\circ}$ ) Conservación: No existe peligro, ni se causa ningún tipo de daño, directo o indirecto, en el patrimonio, y el estado de conservación de los tres monumentos es Muy Bueno o excepcionalmente bueno.

$7^{\circ}$ ) Impacto visual: No existe, a ras de suelo, posibilidad de ver la Torre Pelli desde los 3 elementos inscritos en la Lista de Patrimonio Mundial. No existe ningún impacto visual desde los 3 elementos inscritos. La evaluación de impacto visual ha sido realizada por Ayuntamiento, Comunidad Autónoma y Estado y en todos esos informes se concluye que no existe impacto y no existe elemento que pueda llegar a pertubar la contemplación de estos bienes. Por su parte, ICOMOS no ha elaborado ninguno, sólo con lo que ellos sostienen faltando, a veces, a la realidad fáctica.

$8^{\circ}$ ) Competencia de ICOMOS: Existe extralimitación competencial, aunque habitual, de ICOMOS.

$\left.9^{\circ}\right)$ Revalorización: Existe mejora del entorno con las peatonalizaciones y restauraciones.

$10^{\circ}$ ) Gestión: Existe legislación Nacional y autonómica más que suficiente para garantizar toda protección del "conjunto monumental" inscrito. Aparte se secundar esa tutela los instrumentos de planificación (en base a un evidente principio de jerarquía normativa). Asimismo, existen mecanismos de protección individuales (BIC) y del entorno (Casco Histórico de Sevilla, también BIC) para cada una de las propiedades inscritas, con lo que queda garantizado el valor universal excepcional ("sobresaliente"). Y sobre el particular, exponer que se han respetado todas las normas de directa aplicación, así como todos los parámetros de protección de patrimonio histórico-artístico y cultural. De ahí que todos los informes existentes emitidos por las Administraciones territoriales españolas (local, autonómico y nacional) son positivos y en ninguno se observa quebranto de norma alguna que afecte a la protección patrimonial.

Es de evocar que nuestra legislación, dentro del "entorno a salvaguardar” contempla, por ejemplo, las "perspectivas que ofrezcan los conjuntos urbanos de características histórico-artísticas”, con lo que incluso tenemos mayor determinación de tutela que en algunas instancias internacionales.

$\left.11^{\circ}\right)$ ¿Zona de transición?: Los autores de los Informes de ICOMOS mencionan incluso términos que no tienen ni fundamento, ni apoyo en ningún texto. Así, por ejemplo, utilizan deliberadamente la locución "transitional territory", cuando en esos textos oficiales relativos a la Convención jamás se alude a una pretendida zona de transición.

$12^{\circ}$ ) En lo atinente al entorno en donde se lleva a efecto la construcción de la Torre Pelli en Sevilla, está constituido por La Cartuja el cual está constituido por terrenos baldíos o de zonas de arquitectura moderna de finales del siglo $X X^{183}$.

$13^{\circ}$ ) Ordenamiento jurídico español. Con todos mis respetos, me parece que el proceder de ICOMOS supone un completo desprecio por las normas españolas, por cuanto ellos mismos podrían haber presentado alegaciones contra los instrumentos de planeamiento (PGOU y PERI), o incluso haber acudido a la jurisdicción correspondiente (por ejemplo, por la acción pública ${ }^{184}$ ) si entendían que no se cumplen algunos de los parámetros de protección

182 Punto (o párrafo) 103 (dentro del apartado II.F) de las Directrices Prácticas para la aplicación de la Convención del Patrimonio Mundial.

183 Con la excepción del Monasterio de Santa María de las Cuevas (o Monasterio de la Cartuja). La Cartuja de Santa María de las Cuevas fue declarada Monumento Histórico-Artístico el 27 de Agosto de 1964, junto a otras zonas de la ciudad de Sevilla; Decreto $2803 / 1964$, de 27 de Agosto (BOE num.220 de 12 de Septiembre), y actualmente tiene la consideración como Bien de Interés Cultural según la Disposición Adicional Segunda de la Ley 16/1985 de PHE. El 12 de Abril de 1994, por Resolución de la Dirección General de Bienes Culturales se incoa expediente para la delimitación del entorno afectado por la declaración de la Cartuja de Santa María de las Cuevas, en Sevilla, como BIC (categoría Monumento).

184 Ex arts. 4 y 48 del TRLS/08. 
(tanto de las normas de aplicación directa, como las propias de la legislación autonómica de Patrimonio Histórico de Andalucía), por ejemplo, por presunta afección o "contaminación visual o perceptiva”, y al objeto de revocar, si es lo que entendían, las autorizaciones administrativas otorgadas (que recordemos tienen el carácter de ser regladas). ¿Esa es la forma de auspiciar el respeto mutuo a que se hace hincapié desde la UNESCO?

$14^{\circ}$ ) Orden internacional. Lo que llama la atención es que se vayan cambiando las Directrices Prácticas para la aplicación de la Convención del Patrimonio Mundial. No pasaría nada si ello no se intentase aplicar con carácter retroactivo a monumentos ya inscritos, pues con ese proceder se quebrantan los principios de seguridad jurídica, la buena fe y la propia confianza legítima.

$15^{\circ}$ ) Cruzada de ICOMOS a los edificios en Altura. Ante el proceder de esos “informes de conservación” de los monumentos Patrimonio de la Humanidad y las "amenazas" que con ellas se vienen vertiendo a las diversas Administraciones de incluir esos monumentos en la Lista de monumentos en peligro o incluso con la intimidación de excluir el bien de la Lista de Patrimonio Mundial, sólo tenemos que mirar a Londres y ver que tras más de diez años, ICOMOS no ha conseguido su propósito, ni de parar, ni de demoler los edificios en altura que allí se han construido (o se están construyendo). Idéntico resultado es el que podemos esperar del Comité al objeto de preservar estos Bienes de Sevilla declarados de Patrimonio Mundial por la UNESCO en 1987 (Catedral, Alcázar y Archivo de Indias), por palmaria, notoria y manifiesta inexistencia de "peligro grave" de los mismos.

Como aludíamos más arriba, no podemos comprender que se vulnere el principio de legalidad en su vertiente internacional, que conllevaba (según manifestábamos), por un lado, un ordenamiento jurídico completo, cabal y claro, por otro, la igualdad ante la ley de todos los sujetos de dicho ordenamiento, por otro, la efectiva aplicación del Derecho y, por último, la ausencia de poder arbitrario, desechando toda acción despótica, caprichosa o irresponsable frente a la regulación legal. Parafraseando a Massimiliano Fuksas, deberíamos aplicar "Menos estética y más ética”185.

185 La séptima edición de la Bienal de Arquitectura de Venecia (2000), fue dirigida por el arquitecto italiano Massimiliano Fuksas, reconocido por sus teorías conceptuales, quien propuso el tema de "Menos Estética y Más Ética". 